\title{
Educational Assimilation of First-Generation and Second-Generation Immigrants in Germany
}

\author{
Thomas Gries $^{1} \cdot$ Margarete Redlin ${ }^{1}$ (D) $\cdot$ Moonum Zehra ${ }^{1}$
}

Accepted: 3 June 2021/Published online: 12 July 2021

(C) The Author(s) 2021

\begin{abstract}
Using data from the German Socio-Economic Panel for 1984-2018, we analyze the intergenerational education mobility of immigrants in Germany by identifying the determinants of differences in educational stocks for first- and second-generation immigrants in comparison to individuals without a migration background. Our results show that on average, first-generation immigrants have fewer years of schooling than native-born Germans and have a disproportionate share of lower educational qualifications. This gap is strongly driven by age at immigration, with immigration age and education revealing a nonlinear relationship. While the gap is relatively small among individuals who migrate at a young age, integrating in the school system at secondary school age leads to large disadvantages. Examining the educational mobility of immigrants in Germany, we identify an inter-generational catch-up in education. The gap in education between immigrants and natives is reduced for the second generation. Finally, we find that country of origin differences can account for much of the education gap. While immigrants with an ethnic background closer to the German language and culture show the best education outcomes, immigrants from Turkey, Italy, and other southern European countries and especially the group of war refugees from Syria, Afghanistan, Iraq and other MENA countries, have the lowest educational attainment.
\end{abstract}

Keywords Immigration - Education · Human capital · Education differentials · Intergenerational education mobility · Educational assimilation · Germany · SOEP

JEL Classification F22 $\cdot \mathrm{I} 21 \cdot \mathrm{J} 24 \cdot \mathrm{J} 61$

Margarete Redlin

margarete.redlin@wiwi.upb.de

Extended author information available on the last page of the article 


\section{Introduction}

According to the German Federal Statistical Office (Destatis, 2020), around 21.1 million individuals - $26 \%$ of Germany's population - have an immigration background. Moreover, that number is expected to continue climbing. ${ }^{1}$ German immigration law is fairly liberal compared to that of other countries, and the government has been keen to encourage immigration in recent decades to address the country's low birth rate and invite more skilled labor. In December 2018, Chancellor Angela Merkel's cabinet passed an immigration act focused on attracting skilled workers from outside the EU in an attempt to remedy a chronic labor shortage. ${ }^{2}$ In addition, a strong increase in immigration caused by the refugee crisis has been observed since 2014 . This significant increase in the German population with a migration background makes it a current and controversial topic and poses a challenge for the German authorities. The major challenges include migrants' integration into the culture and social system and the provision of opportunities for them to develop educational and professional skills and cope with cultural shocks. Immigration is often claimed to be a key contributor to productivity and economic growth; also, empirical evidence shows it has a positive long-run effect on TFP (Herzer, 2017; Peri, 2012), on GDP growth (Boubtane et al., 2016; Bove \& Elia, 2017), and on innovation (Burchardi et al., 2020). However, the observed relationship between immigration and growth strongly depends on many factors, including skill composition and rate of assimilation (Borjas, 2019). The secular structural change to the tertiary sector, technological change, and digitization are accompanied by, on average, higher qualification requirements and polarization of job opportunities. This increases demand for highly qualified workers. Since that demand cannot be fully covered by domestic labor, cross-country competition for high-skilled immigrants has risen (Docquier \& Machado, 2016). Thus, while highly skilled migrants can easily be integrated into the labor market to meet that demand, labor market opportunities for low-skilled migrants are limited (Ho \& Turk-Ariss, 2018; Kahn, 2004). In general, for first-generation immigrants, the process of human capital accumulation starts with the education and skills they acquire in their home country before they decide to migrate, and in some cases continues in the host country with additional investments in education (De Paola \& Brunello, 2016). In between these two periods, migrants must adjust to a new learning environment and obtain the required language skills. Therefore, integrating migrants in the labor market is a question not only of entered human capital, but also of educational integration in the destination country.

According to the German Microcensus, individuals with a migration background on average have lower levels of education than native Germans. For example, the proportion of citizens aged between 18 and 25 without a school-leaving certificate is $1.4 \%$ for individuals without a migration background and $9.6 \%$ for those with. This also has an effect on employment, resulting in significant differences in unemployment rates of

\footnotetext{
${ }^{1}$ According to the definition of the German Federal Statistical Office, individuals have a migration background if they or at least one parent did not receive German citizenship at birth.

${ }^{2}$ The new rules allow skilled workers from outside the European Union to search for work in Germany for a period of 6 months, provided they have the means to fund their stay and have knowledge of the German language. While under the old rules that opportunity was reserved only for highly qualified workers, the new law is also directed at less qualified workers.
} 
$2.6 \%$ and $6 \%$ for individuals without and with a migration background, respectively (German Federal Statistical Office, 2020).

Successful integration depends not only on the social-economic shifts that take place during the life cycle of the immigrant population, but also on the adjustment process experienced by immigrant households across generations. In other words, integration is also a question of social mobility. For the U.S.A., Borjas (2006) identifies a significant economic "catching-up" between the first and second generations of immigrants, while Chiswick and DebBurman (2004) find that although first-generation migrants show the lowest educational attainment, second-generation migrants have the highest level of schooling, higher than that of the first generation and of native U.S. citizens.

Germany suffers from severely low social mobility across generations. Germans' income and professional status are strongly dependent on that of their parents, and moving to a higher position is very difficult (Hradil \& Schiener, 2001; Legewie \& Bohmann, 2018). A recent OECD report claims that children from low-income families find it harder to climb the social ladder in Germany than in any other industrialized country. Upward "inter-class" movement is practically impossible in Germany, which sociologists blame on the education system and tax and childcare policies (OECD, 2018a).

Given that immigrants have a lower level of educational attainment, their limited social mobility may impede integration from one generation to the next. Analyzing intergenerational mobility of immigrants and natives in Germany, Yuksel (2009) shows that native Germans have better social mobility than immigrants. Contrary to the U.S. results, which suggest that immigrants' earnings converge toward those of natives (Borjas, 1993), the results for Germany suggest that immigrant earnings diverge (Yuksel, 2009).

In the debate on educational assimilation of immigrants in Germany, existing literature usually focuses on one specific aspect, such as immigration generation (Fick, 2011; Kristen \& Granato, 2007), age at arrival (Lemmermann \& Riphahn, 2018), ethnic differences (Diehl et al., 2016; Müller \& Stanat, 2006), or a particular group of immigrants (Bönke \& Neidhöfer, 2018; Hartmann, 2016). However, looking at isolated factors delivers only limited insights and hence an incomplete picture. To identify the level of long-term educational assimilation, it is more expedient to evaluate differences between immigration generations and compare their opportunities to achieve certain outcomes to those enjoyed by natives. In addition, examining different immigration groups and their characteristics over a long period helps explore potential differences in educational catch-up across regional backgrounds and ages at arrival over time and for specific immigration generations. Our approach follows that of Chiswick and DebBurman (2004), who examine the drivers of educational attainment for immigrants and natives for the U.S.A.

Our empirical analysis adds to the existing literature by taking a comprehensive look at educational opportunities of immigrants in Germany and giving a detailed picture of the assimilation process based on a large and recent micro sample with a simultaneous consideration of various aspects. In particular, using data from the German SocioEconomic Panel (SOEP), we conduct a detailed analysis by simultaneously examining educational attainment measured by years of schooling and the probability of attaining a certain education level for first- and second-generation immigrants in comparison to native-parentage adults in combination with cultural differences and the effect of age at 
migration. Our methodological concept allows us to examine differences in educational attainment based on migration background as well as the adjustment to the German education system, explore the inter-generational catch-up in education, and focus on differences in social mobility between migrants and natives. We use survey micro-data from 1984 to 2018, which allows us to include past labor immigration, the wave of ethnic German repatriates, as well as more recent waves of war refugees, as well as to identify differences in the effects on education between these groups. In particular, the last wave of refugee migration has received insufficient attention in the empirical literature. Further, we control for age at immigration to analyze the life-cycle effects that determine how immigrants adapt to the German education system. Finally, we control for country of origin to analyze the effect of ethnic identities that captures cultural and language disparities. Studying these factors concurrently allows us to determine differences in level of education based on an individual's background and personal characteristics such as gender, age, and family status.

The remainder of the paper is structured as follows. Chapter 2 reviews the relevant literature, addresses the factors influencing the relationship between immigration background and educational attainment, and develops the test hypotheses for the empirical examination. Chapter 3 presents the analysis including the data, methodology, and results, while the last and fourth chapter details the implications and concludes.

\section{Education and Immigration Background}

The relationship between family background and academic success is one of the central themes of educational inequality research. Beside socioeconomic status and parental educational attainment, the migration status of an individual and their family, too, seems to explain disparities in education (Björklund \& Salvanes, 2011; Lauderdale \& Heckman, 2017). International standardized assessments of educational attainment have shown that immigrant students in most countries score lower than native students (Maehler et al., 2014; OECD, 2016a, 2016b; Reiss et al., 2016). A recent OECD (2017) report evaluates the results of the 2015 PISA study $^{3}$ (OECD, 2016a) and the 2016 PIAAC $^{4}$ study (OECD, 2016b), showing that children with immigrant parents face a persistent disadvantage in the education system and the transition from school to work. Especially for Germany, the results show a pronounced relationship between academic success and family origin. Empirical surveys of immigrants in Germany reveal a significant educational gap between children and adolescents from families with and without a migration background (Baumert et al., 2003; Diehl et al., 2016; Müller \& Stanat, 2006; Schnabel \& Schwippert, 2000; Segeritz et al., 2010; Stanat, 2006; Walter, 2008; Weiß \& Nussbaum Bitran, 2019). This can also be observed for other countries. Chiswick and DebBurman (2004) find that U.S. immigrants show on average less educational attainment than U.S.-born individuals. Schnepf (2007) analyzes ten OECD countries $^{5}$ and finds that in all cases, immigrant pupils lag behind native pupils in

\footnotetext{
3 The PISA study tests students' educational attainment and includes data on their socioeconomic background, immigration status, and parental nativity for OECD countries.

${ }^{4}$ PIAAC is an international comparative survey by the OECD that assesses key adult competencies.

${ }^{5}$ Australia, Canada, France, Germany, the Netherlands, New Zealand, Sweden, Switzerland, the UK, and the USA.
} 
educational achievement, although the English-speaking countries reveal much smaller differences than those in continental Europe.

\section{Immigration Generation}

An important factor in the relationship between immigration and education is intergenerational assimilation. The OECD addresses this educational convergence process in its recent reports (OECD, 2017; OECD, 2018b) "Catching Up? Intergenerational Mobility and Children of Immigrants" and "Catching Up? Country Studies on Intergenerational Mobility and Children of Immigrants," arguing that although in most OECD countries, second-generation immigrants still perform worse on education and the education-to-labor market transition, their performance is substantially improved over that of their parents' generation. E.g. across European OECD countries, secondgeneration immigrants have on average 1.3 years more schooling than their parents, while their peers with native-born parents are ahead by 0.7 years. Analyzing educational outcomes of children from immigrant families over the generations, existing studies indicate an intergenerational reduction in the disadvantage of immigrants that points at a convergence toward the native population's educational level.

The speed of convergence, however, varies by country and within countries between different regional groups. For instance, examining educational differences between first- and second-generation immigrants and native individuals, van Ours and Veenman $(2001,2006)$ find that first-generation immigrants in the Netherlands, especially from Turkey and Morocco, perform worse than native Dutch. While there is a gap in educational attainment between second-generation immigrants and native Dutch, when controlling for parental education these differences largely vanish. Sweetman and van Ours (2015) and Dimitrova et al. (2016) confirm this result for the Netherlands and other European countries, indicating that first-generation immigrants have the lowest educational attainment while second-generation immigrants catch up. Chiswick and DebBurman (2004) analyze the case of the U.S.A. and find that while first-generation immigrants lag behind in terms of schooling, second-generation immigrants, in particular Asians, have the highest level of schooling, exceeding that of their foreign-born and native-born peers with native-born parents.

Investigating the case of Germany, Algan et al. (2010) compare education outcomes of natives and first- and second-generation immigrants. Their results show that all groups of first-generation immigrants have significantly less education than native Germans. The difference is particularly pronounced for immigrants from Germany's traditional "Gastarbeiter" (guest worker) countries. For the second generation, the results show a significant improvement in educational attainment although secondgeneration immigrants from Turkey, former Yugoslavia, and Italy remain significantly less educated than natives. Analyzing the educational success of German-born children of immigrants, Riphahn (2003) finds that their academic success still lags behind that of natives and that the educational gap remains large and significant. Kristen and Granato (2007) confirm this result and argue that second-generation youngsters, in particular with Turkish and Italian descent, experience pronounced disadvantages over their German peers. Alba et al. (2017), however, argue that the education disadvantage of children of immigrants is generally much smaller than that of first-generation immigrants and find improved educational outcomes for this group. This catch-up process 
can be attributed to improved language skills and greater parental aspiration and system knowledge (OECD, 2017). Nevertheless, differences in educational attainment between individuals with and without an immigration background remain significant. They can be traced back to socio-economic differences and differences in parental education (van Ours \& Veenman, 2001) combined with general low social mobility. Following this argumentation and the identified differences in the descriptive statistics for the case of Germany, in a first step we regress educational outcomes controlling for status (native, first generation, second generation) and analyze the latest SOEP dataset to test the following hypotheses:

H1a: Immigrants have lower educational attainment and poorer academic achievement than their German counterparts.

H1b: The education gap between immigrants and natives is smaller for the second immigration generation than for the first.

\section{Immigration Age}

Recent immigration research has identified several factors affecting the relationship between migration background and educational attainment. First, age at immigration is shown to have an effect on education. Empirical studies find a non-linear U-shaped relationship between educational attainment and age at immigration for the case of the U.S.A. (Chiswick \& DebBurman, 2004; Chiswick \& Sullivan, 1995; Cortes, 2006), for Canada (Corak, 2012; Schaafsma \& Sweetman, 2001), and for Australia (Chiswick \& Miller, 1994), where years of schooling first decrease and then increase with age at immigration, indicating that individuals who migrated at secondary school age acquire less total education than those who immigrated at pre-teen or post-teen ages. Lemmermann and Riphahn (2018) analyze causalities between age at immigration and education for the case of Germany and the SOEP survey years 1984-2013. Based on a sample of immigrant children with siblings who immigrate at different ages, they find that it is beneficial to migrate early in life. Above a critical age of six, there is a strong negative impact on performance. Böhlmark (2008) confirms this result for the case of Swedish immigrants, while van Ours and Veenman (2006) find similar results for the Netherlands. While the process of adaptation is easier for children that migrate at a young age, adjusting to a new environment is more difficult for adolescent and adult migrants. Following this evidence, we analyze the latest data until 2018 to test this relationship and expect to find support for the following hypothesis:

H2: Age at immigration has a nonlinear effect on educational outcome. A younger age at arrival increases the educational opportunities of immigrants.

\section{Regional Origin}

When investigating educational outcomes of immigrants in Germany, existing studies also point out a substantial origin-related effect (Gang \& Zimmermann, 2000). For the case of the U.S.A., Asian immigrants are found to outperform other groups in 
educational outcomes, having a schooling level even greater than that of their nativeborn peers; European and Canadian immigrants have a schooling level similar to that of the native population; and Central and South American students have lower achievement levels and higher dropout rates (Chiswick \& DebBurman, 2004; Cohen et al., 1997; Kao \& Thompson, 2003; Kirui \& Kao, 2018; Tran et al., 2019). For Germany, there is evidence of significant differences in educational attainment between countries of origin. Gang and Zimmermann (2000) analyze education outcomes for labor migration from Turkey, Italy, Yugoslavia, Greece, and Spain and find not only differences to the native population but also differences between countries of origin. Studies investigating a larger set of countries of origin find that while Polish, Russian, and Croatian students are able to integrate relatively well into the German education system, students from Turkey, Italy, Serbia, and Montenegro score comparatively poorly (Alba et al., 2017; Riphahn, 2003; Siegert, 2008). Ramírez-Rodríguez and Dohmen (2010) analyze the determinants of origin-related differences in Germany and argue that a migrant family's cultural, economic, and social capital may have an effect on the educational decisions parents make for their children. The authors argue that ethnic background and parents' educational aspirations influence the transition from elementary to secondary education with far-reaching implications for young people's educational and career biographies. The authors also highlight the importance of language, indicating that the acquisition of the host society's language is considered a fundamental cultural resource through which other resources can be obtained. For school-age children, using German as the main home language is positively correlated with reading and writing skills. Finally, they trace back origin-related differences in education investment decisions to socio-economic disparities. However, since the most recent studies date back a few years, the wave of war refugees that reached Germany is not considered here. We use new data that takes into account not only the migration of guest workers who came to Germany between the late 1950s and early 1970s and the ethnic German repatriates who immigrated in the 1980s and 1990s, but also the refugees who migrated to Germany mainly from Syria, Afghanistan and Iraq in 2014 and later. This allows us to identify differences between countries of origin and between different waves of immigration based on different phases, reasons for migration, and immigration laws and test the following hypothesis:

H3: The educational gap of immigrants is contingent upon their regional background and it differs for different waves of immigration.

In the following chapter we examine the established hypotheses.

\section{Empirical Analysis}

The empirical analysis focuses on the determinants of differences in educational attainment for immigrants and non-immigrants in Germany for the period 19842018. In a first step, we examine the drivers of educational stock and the probability of certain educational outcomes of first-generation, second-generation, and nativeparentage adults in a pooled sample. In a second step, we focus on the firstgeneration sample to obtain deeper insights into the determinants for this group. 


\section{Data}

The analysis is based on data from the German Socio-Economic Panel (SOEP), a wideranging representative longitudinal study of private households in Germany that commenced in 1984 and covers a wide range of variables on topics such as household composition, occupational biographies, earning and employment history, migration background, and other socio-economic aspects. This dataset is highly suitable for our analysis because it offers information on immigrant generation, age at immigration, and country of origin. ${ }^{6}$

Since we restrict ourselves only to certain variables from the SOEP, this reduces the sample size. The total sample size from SOEP for the period 1984-2018 and our variable selection covers 96,792 observations. To minimize errors, all interviews that do not provide an answer on number of years of education are excluded from the sample, as this is one of the main variables of interest. In addition, to ensure comparability between individuals, our sample is limited to adults who have already completed their education ( 24 or older), leading to a final sample of 78,118 observations.

Further, we generate subsamples with regard to migration background, where we distinguish between first- and second-generation immigrants and natives. According to this differentiation, the sample size of first-generation, second-generation, and native adults is $20,794,33,368$ and 53,956 , respectively.

\section{Dependent Variable}

The dependent variable educational attainment (EDU) measures the number of years of education. For second-generation immigrants and native individuals, this reflects education acquired in Germany. For first-generation immigrants, it reflects the years of schooling completed in the country of origin before immigration as well as education in Germany after immigration. Further, the SOEP dataset enables us to distinguish between educational levels in the categories lower than high school (LHS), high school (HS), and more than high school (MHS). ${ }^{7}$

\section{Explanatory Variables}

First, we control for immigration status by distinguishing between first-generation and second-generation immigrants and native-parentage individuals. As per definition, in the SOEP dataset, "first-generation" includes all individuals with a direct migration

\footnotetext{
${ }^{6}$ The exact variable selection with the corresponding SOEP variable definitions is available in Table 9 in the Appendix.

${ }^{7}$ Germany has a three-parted school system. The first 4 years of elementary school are obligatory for everybody. After that, students are separated according to their academic ability and go on to attend one of three different kinds of secondary schools: Hauptschule, Realschule or Gymnasium. The Hauptschule (grades 5-9) teaches the same subjects as the Realschule and Gymnasium, but at a slower pace and with some vocational-oriented courses. It leads to part-time enrollment in a vocational school combined with apprenticeship training until the age of 18 . The Realschule (grades 5-10) leads to part-time vocational schools and higher vocational schools. The Gymnasium encompasses grades 5 to 13 (or 5 to 12 ) and leads to a diploma called the Abitur. It prepares students for university study or for a dual academic and vocational credential. In our analysis, Hauptschule and Realschule form category "lower than high school" and Gymnasium the category "high school".
} 
background (country of origin other than Germany); "second-generation" consists of all individuals with an indirect migration background (German-born with either one or both parents born outside Germany); and "native-parentage" individuals are natives or third- or later-generation immigrants (German-born with both parents born in Germany).

Second, we account for the effect of age at immigration and age at immigration squared (age at immigration $^{2}$ ) since we expect a better adjustment to a new environment at a younger immigration age.

Expecting differences with regard to regional origin in educational attainment, we assume different countries of origin to have a varying influence on schooling. For example, individuals migrating to Germany from European countries may experience a weaker cultural shock than those from Asian or MENA countries, where language barriers are higher, too. Country of origin is used as a dummy variable to capture the country or region of origin. By creating regional dummies, we are also able to record the individual migration phenomena in Germany separately. The migration of guest workers is captured by the dummies for Turkey, Italy, and Southern Europe; immigration of German late repatriates is captured by the dummies for the former USSR, Poland, and Eastern Europe; and immigration during the refugee crisis is covered by dummies for the MENA region, Syria, Afghanistan and Iraq. ${ }^{8}$

Further, we control for demographic characteristics and include gender (with a dummy variable $1=$ male) and marital status (with a dummy variable $1=$ married) in the specification.

We also account for the effect of age. While age at immigration is assumed to imply the ability to adapt to a new educational environment, it is also assumed to have an effect on education accumulated during one's lifetime. As the relationship between age and educational attainment is expected to be positive but at a decreasing rate, we also include age squared $\left(\operatorname{age}^{2}\right)$. Using age as a determinant of educational attainment is essential here, as it reflects not only the cohort effect, but also the life cycle effect. The cohort effect implies that younger cohorts tend to acquire comparatively more education, while the life cycle effect accounts for the fact that education increases as individuals become older.

Finally, we control for geographic differences. We expect that individuals in eastern Germany may have different circumstances from those in western Germany, thus we include a dummy (1 = eastern Germany) for geographic location.

\section{Descriptive Statistics}

Table 1 shows the statistical summary for each sub-sample. On average, firstgeneration immigrants show lowest educational attainment with around 10 years of schooling. Second-generation and native-parentage adults acquire around 2.4 years more education than their first-generation peers. The difference between these two groups is small, with 0.06 years less education for the native group. Considering educational levels, the picture is similar. Individuals with a migration background show on average a lower level of education. While only $12 \%$ of native-parentage

\footnotetext{
${ }^{8}$ Detailed information on the country of origin dummies and their classification is available in the data appendix.
} 
Table 1 Means and standard deviations of variables for first-generation, second-generation, and nativeparentage adults, Germany, 1984-2018

\begin{tabular}{llll}
\hline Variable & First-generation & Second-generation & Native-parentage \\
\hline Educational attainment & $10.01(2.24)$ & $12.41(2.89)$ & $12.35(2.72)$ \\
Education LHS & $0.45(0.50)$ & $0.18(0.38)$ & $0.12(0.32)$ \\
Education HS & $0.31(0.31)$ & $0.59(0.49)$ & $0.63(0.48)$ \\
Education MHS & $0.20(0.40)$ & $0.23(0.42)$ & $0.25(0.43)$ \\
Male & $0.51(0.50)$ & $0.49(0.50)$ & $0.48(0.50)$ \\
Age & $43.72(13.46)$ & $38.27(11.07)$ & $53.40(16.88)$ \\
Married & $0.73(0.44)$ & $0.55(0.50)$ & $0.68(0.47)$ \\
Age at immigration & $26.69(13.80)$ & & 53,956 \\
Sample size & 20,794 & 3,368 & \\
\hline
\end{tabular}

Note: Standard deviations in parentheses

individuals have an education level lower than high school, the share is much higher for individuals with a migration background ( $45 \%$ for first-generation and $18 \%$ for secondgeneration migrants). For the education levels "high school" and "more than high school," the picture is reversed. Here, the share of high school and university graduates is much lower in the groups of individuals with a direct or indirect migration background than in the native-parentage group. The average age of first-generation immigrants in the sample is 44 while age at immigration is 27 years. In all generations, nearly half of the population is male and more than half are married.

\section{Pooled Sample Analysis}

The starting point of our analysis is a regression over a pooled sample of firstgeneration and second-generation immigrants and native-parentage individuals to test hypotheses $H 1 a$ and $H 1 b$ and identify whether immigration background is a significant determinant for the above differences in educational attainment. To account for this effect, we include dummies for first-generation and second-generation immigrants illustrating the difference in average years of schooling compared to that of the native-parentage control group.

Table 2 presents the OLS results. The first specification in column one shows the results for general educational attainment expressed in years of schooling (EDU), while the subsequent columns show the results for the dichotomous measures of the highest education level achieved for the categories "lower than high school" (LHS), "high school" (HS), and "more than high school" (MHS). The results confirm hypothesis $H 1 a$ and indicate that migration background significantly decreases educational attainment. The effect of a direct migration background on education is captured jointly by the first-generation dummy and the coefficients of age at immigration and age at immigration squared. Holding all other variables constant, first-generation immigrants show on average a difference of $-0.993-0.095$ (age at immigration) +0.00104 (age at immigration $)^{2}$ years in education compared to their native-parentage peers. 
Table 2 Regression estimates of pooled sample of first-generation, second-generation, and native-parentage adults, Germany, 1984-2018

\begin{tabular}{|c|c|c|c|c|}
\hline Variable & EDU & LHS & HS & MHS \\
\hline Constant & $\begin{array}{l}11.330 * * * \\
(123.14)\end{array}$ & $\begin{array}{l}0.446^{* * * *} \\
(33.38)\end{array}$ & $\begin{array}{l}0.429 * * * \\
(25.15)\end{array}$ & $\begin{array}{l}0.082^{* * * *} \\
(5.36)\end{array}$ \\
\hline Male & $\begin{array}{l}0.294 * * * \\
(16.10)\end{array}$ & $\begin{array}{l}-0.072 * * * \\
(27.00)\end{array}$ & $\begin{array}{l}0.031 * * * \\
(9.15)\end{array}$ & $\begin{array}{l}0.046^{* * * *} \\
(15.24)\end{array}$ \\
\hline Age & $\begin{array}{l}0.061 * * * \\
(17.26)\end{array}$ & $\begin{array}{l}-0.014 * * * \\
(26.21)\end{array}$ & $\begin{array}{l}0.008 \\
(12.46)\end{array}$ & $\begin{array}{l}0.007 * * * \\
(11.57)\end{array}$ \\
\hline $\mathrm{Age}^{2}$ & $\begin{array}{l}-0.0008 * * * \\
(24.65)\end{array}$ & $\begin{array}{l}0.0001 \text { *** } \\
(30.91)\end{array}$ & $\begin{array}{l}-0.0001 * \\
(13.38)\end{array}$ & $\begin{array}{l}-0.0001^{* * * *} \\
(14.20)\end{array}$ \\
\hline Eastern Germany & $\begin{array}{l}0.045 \\
(1.88)\end{array}$ & $\begin{array}{l}-0.053 * * * \\
(15.45)\end{array}$ & $\begin{array}{l}0.037 * * * \\
(8.54)\end{array}$ & $\begin{array}{l}0.012 * * * * \\
(3.09)\end{array}$ \\
\hline Married & $\begin{array}{l}0.087 * * * \\
(4.14)\end{array}$ & $\begin{array}{l}-0.014 * * * \\
(4.59)\end{array}$ & $\begin{array}{l}-0.013 * * * \\
(3.35)\end{array}$ & $\begin{array}{l}0.023 * * * \\
(6.67)\end{array}$ \\
\hline Age at immigration & $\begin{array}{l}-0.095 * * * \\
(26.13)\end{array}$ & $\begin{array}{l}0.013 * * * \\
(23.96)\end{array}$ & $\begin{array}{l}-0.017 * * * \\
(25.24)\end{array}$ & $\begin{array}{l}0.003^{* * * *} \\
(5.70)\end{array}$ \\
\hline Age at immigration $2 / 100$ & $\begin{array}{l}0.104 * * * \\
(16.84)\end{array}$ & $\begin{array}{l}-0.015^{* * * *} \\
(16.43)\end{array}$ & $\begin{array}{l}0.016^{* * * *} \\
(14.21)\end{array}$ & $\begin{array}{l}-0.004 * * * \\
(3.93)\end{array}$ \\
\hline First-generation & $\begin{array}{l}-0.993 * * * \\
(18.55)\end{array}$ & $\begin{array}{l}0.141 \text { *** } \\
(18.12)\end{array}$ & $\begin{array}{l}-0.017 \\
(1.72)\end{array}$ & $\begin{array}{l}-0.119 * * * \\
(13.41)\end{array}$ \\
\hline Second-generation & $\begin{array}{l}-0.220^{* * *} \\
(4.73)\end{array}$ & $\begin{array}{l}0.068^{* * * *} \\
(10.12)\end{array}$ & $\begin{array}{l}-0.038^{* * *} \\
(4.37)\end{array}$ & $\begin{array}{l}-0.027 * * \\
(3.46)\end{array}$ \\
\hline Adjusted $\mathrm{R}^{2}$ & 0.174 & 0.162 & 0.100 & 0.012 \\
\hline Sample size & 78,118 & 78,118 & 78,118 & 78,118 \\
\hline
\end{tabular}

Note: $t$-statistics in parentheses; $* \mathrm{p}<0.10, * * \mathrm{p}<0.05$, *** $\mathrm{p}<0.01$; EDU $=$ educational attainment measured by average years of schooling. LHS, HS, and MHS represent dichotomous variables capturing the highest education level with the categories "lower than high school," "high school," and "more than high school;" benchmark group comprises all native adults

Further, the negative effect on education for the second-generation dummy is smaller than for the first generation dummy, confirming hypothesis $H 1 b$ and indicating that the gap in education is smaller for immigrants' children. Although there seems to be convergence across generations - the distance between second-generation and native-parentage individuals is smaller than that between first-generation and native individuals - there is still a disadvantage of 0.22 years of schooling for the second generation compared to the natives. This identified assimilation in the acquisition of education is consistent with the results of Gang and Zimmermann (2000) for Germany and the country studies of the OECD (2018b) for several European countries, indicating that the gap in educational attainment between immigrants in Germany and their German-born peers is much smaller among the second generation than the first. That said, results for the U.S.A. provide contrary evidence, with second-generation immigrants found to be better off than not only first-generation immigrants but also natives (Batalova \& Feldblum, 2020; Chiswick \& DebBurman, 2004; Taylor et al., 2013). These differences may be due to different migration motives, differences in ethnicity, and differences in migration policy. Drouhot and Nee (2019) investigate which factors potentially account for different patterns of second-generation integration in different 
countries. Comparing and contrasting immigrant trajectories in Western Europe and North America, they find that assimilation is contingent upon path-dependent mechanisms motivated and guided by institutional rules, cultural beliefs, and networks effects (Nee \& Alba, 2013). A more selective immigration policy in the U.S.A. with caps on immigration and stronger preferences for skilled immigration (Bertoli \& Brücker, 2011) resulted in a positive educational selectivity, especially for migration from Asia (Feliciano, 2005). Further, for US immigrants, legal status has been identified as a key institutional rule affecting national identity and channeling immigrants and their children into specific integration pathways (Waters \& Gerstein Pineau, 2016).

The negative and positive signs of age at immigration and age at immigration squared, respectively, confirm hypothesis $H 2$ and indicate a non-linear relationship where educational attainment decreases with age at immigration at a decreasing rate. While immigrants have a smaller gap in educational attainment than native individuals provided they migrate at a young age, this gap widens with increasing age at migration. Compulsory schooling and better social integration at a young age may improve access to the German education system, while rising language barriers (Esser, 2006) and acculturation problems that increase with age may impede educational integration.

The positive sign of age and the negative sign of age squared imply a nonlinear relationship between age and education outcome, indicating that education is acquired particularly in the early stages of life and that the rate of educational attainment declines with increasing age. Finally, controlling for geographic differences and an impact of social conditions on educational outcomes, we find positive results for the male and the married dummies for all specifications. Family living conditions seem to have an effect on competence acquisition and lead to higher educational attainment, however, the magnitudes of the effects are rather small, with 0.3 years for males and 0.1 years for married individuals. The dummy for eastern Germany is not significant, showing that there are no general differences in average years of schooling between eastern and western Germany.

Columns two to four present the results for the dichotomous variables capturing the highest education level. Thus, the coefficient of the constant for LHS indicates that $44.6 \%$ of native population have not completed secondary education or have a qualification lower than high school - which represents the German secondary school variants "Hauptschule" and "Realschule." The results for the dummies for firstgeneration and second-generation immigrants again provide confirmation for hypothesis $H 1 a$ and indicate that individuals with a migration background are $14.1 \%$ (first generation) and $6.8 \%$ (second generation) more likely to have not completed secondary school or to have a low qualification. While the share of individuals with an education lower than high school is larger for immigrants, the share of individuals with a high school qualification or higher is smaller for immigrants. First-generation immigrants are $11.9 \%$ and second-generation immigrants $2.7 \%$ less likely to obtain a qualification higher then high school. Again, and in line with hypothesis $H 1 b$, we can observe a convergence in education toward the level of native-born individuals indicated by the smaller coefficients for second-generation immigrants. That said, a gap to the native population still exists.

We expect differences in the effect with respect to the immigrants' country of origin (Alba et al., 2017; Gang \& Zimmermann, 2000), thus in a second step, we take a closer look at the origin of the immigrant population and replace the first-generation dummy 
with country or region of origin dummies to test hypothesis $H 3$. The results, relatively to the benchmark group of native adults, are presented in Table 3. The coefficients illustrate differences in education acquisition between first-generation immigrants from a specific region/country and native-parentage individuals, holding other things constant.

We group the dummies in chronological order based on the different waves of migration and the underlying reasons for migration and immigration laws. The first three dummies represent the wave of guest workers who immigrated to Germany in the 1950s and 60s. We include Turkey and Italy explicitly as countries, while Greece, Spain, and Portugal are grouped in the dummy for Southern Europe. The second group includes the countries of origin of the immigrants who came to Germany as late repatriates in the 1980s and 90s. Here, the countries of the former USSR and Poland are explicitly listed; Hungary, the Czech Republic, and Slovakia are summarized in the dummy for Eastern Europe. The last group includes Syria, Afghanistan, and Iraq. A large proportion of the refugees who arrived in Germany since 2014 come from these countries. MENA includes all other countries in the Middle East and North Africa region. We also include group dummies for South-Eastern Europe, Sub-Saharan Africa, Northern and Western Europe, Asia, and all remaining countries.

While immigrants from northern and western Europe are found to acquire more education than native adults (approximately 0.4 years), immigrants from all other regions acquire less education than their native-born peers. Immigrants from Turkey, Italy, and other southern European countries show a significantly lower level of education, with $2.3,2.1$, and 1.8 years less than natives, respectively, supporting the results of Müller and Stanat (2006) and Kristen and Granato (2007). Within this group, German language proficiency was mostly nonexistent, and the immigrants' focus was to a large extent on employment in the manufacturing industry rather than on education, causing this group to lag behind in educational attainment. Immigrants from the former Soviet Union, Poland, other eastern European countries, and Asia obtain less education than natives, however the gap is quite small at less than 1 year in all cases. The group of refugees from Syria, Afghanistan, Iraq, and the rest of the MENA region shows the greatest disadvantage in education. The gap is more than 2 years in all cases, and the peaks for Iraq and Afghanistan even show a difference of 2.9 and 3.2 years of education, respectively, compared to the native-born population. This supports the results of Stoewe (2017), which show that a large proportion of the refugees from this region have no or only primary school education. While immigrants from south-eastern Europe show moderate deficits with 1.4 years less education, the gap for Sub-Saharan countries is quite large with 2.1 years less education.

In summary, these differences in education level based on place of origin may reflect differences in migration motives that vary according to social and educational backgrounds and also education systems in the countries of origin. For example, labor migrants from Turkey, Italy, and other southern European countries came mainly as unskilled workers with little school education; only rarely did they have a professional qualification. In the group of immigrants from non-EU countries, higher cultural and language barriers play a greater role, whereas migrants from the former USSR and Poland came as late repatriates and often already had German language skills, which eased their integration into the German education system. Refugees often arrive in Germany with a poor educational background. On the one hand, this is due to the 
Table 3 Regression estimates including country of origin - Pooled sample of first-generation, secondgeneration, and native-parentage adults, Germany, 1984-2018

\begin{tabular}{|c|c|c|c|c|}
\hline Variable & EDU & LHS & HS & MHS \\
\hline Constant & $\begin{array}{l}11.72 * * * \\
(127.11)\end{array}$ & $\begin{array}{l}0.393 * * * \\
(29.58)\end{array}$ & $\begin{array}{l}0.512 * * * \\
(29.88)\end{array}$ & $\begin{array}{l}0.084 * * * \\
(5.45)\end{array}$ \\
\hline Male & $\begin{array}{l}0.345^{* * * *} \\
(19.10)\end{array}$ & $\begin{array}{l}-0.081 * * * \\
(31.05)\end{array}$ & $\begin{array}{l}0.039 * * * \\
(11.70)\end{array}$ & $\begin{array}{l}0.049 * * * \\
(16.37)\end{array}$ \\
\hline Age & $\begin{array}{l}0.048^{* * * *} \\
(13.37)\end{array}$ & $\begin{array}{l}-0.012 * * * \\
(22.81)\end{array}$ & $\begin{array}{l}0.005^{* * * *} \\
(7.92)\end{array}$ & $\begin{array}{l}0.007 * * * \\
(11.34)\end{array}$ \\
\hline $\mathrm{Age}^{2}$ & $\begin{array}{l}-0.0007 * * * \\
(21.67)\end{array}$ & $\begin{array}{l}0.0001 * * * \\
(28.50)\end{array}$ & $\begin{array}{l}0.0001 * * \\
(9.74)\end{array}$ & $\begin{array}{l}0.0001 * * * \\
(14.11)\end{array}$ \\
\hline Eastern Germany & $\begin{array}{l}0.040 \\
(1.72)\end{array}$ & $\begin{array}{l}-0.051 * * * \\
(15.09)\end{array}$ & $\begin{array}{l}0.040^{* * * *} \\
(9.15)\end{array}$ & $\begin{array}{l}0.009 * \\
(2.38)\end{array}$ \\
\hline Married & $\begin{array}{l}0.117 * * * \\
(5.63)\end{array}$ & $\begin{array}{l}-0.017 * * * \\
(5.67)\end{array}$ & $\begin{array}{l}0.008^{*} \\
(2.14)\end{array}$ & $\begin{array}{l}0.024 * * * \\
(6.96)\end{array}$ \\
\hline Age at immigration & $\begin{array}{l}-0.067 * * * \\
(18.37)\end{array}$ & $\begin{array}{l}0.008 * * * \\
(15.72)\end{array}$ & $\begin{array}{l}-0.012 * * * \\
(18.38)\end{array}$ & $\begin{array}{l}0.005 * * * \\
(7.73)\end{array}$ \\
\hline Age at immigration ${ }^{2} / 100$ & $\begin{array}{l}0.077 * * * \\
(12.51)\end{array}$ & $\begin{array}{l}-0.010^{* * * *} \\
(11.18)\end{array}$ & $\begin{array}{l}0.013 * * * \\
(11.13)\end{array}$ & $\begin{array}{l}-0.006^{* * * *} \\
(6.07)\end{array}$ \\
\hline Second-generation & $\begin{array}{l}-0.275^{* * * *} \\
(6.00)\end{array}$ & $\begin{array}{l}0.077 * * * \\
(11.60)\end{array}$ & $\begin{array}{l}-0.048^{* * *} \\
(5.68)\end{array}$ & $\begin{array}{l}-0.028 * * * \\
(3.66)\end{array}$ \\
\hline \multicolumn{5}{|l|}{ Country of origin } \\
\hline Turkey & $\begin{array}{l}-2.280^{* * * *} \\
(32.07)\end{array}$ & $\begin{array}{l}0.380 * * * \\
(37.10)\end{array}$ & $\begin{array}{l}-0.146^{* * * *} \\
(11.02)\end{array}$ & $\begin{array}{l}-0.269^{* * * *} \\
(22.64)\end{array}$ \\
\hline Italy & $\begin{array}{l}-2.137 * * * \\
(23.23)\end{array}$ & $\begin{array}{l}0.343 * * * \\
(25.89)\end{array}$ & $\begin{array}{l}-0.131 * * * \\
(7.67)\end{array}$ & $\begin{array}{l}-0.228 * * * \\
(14.85)\end{array}$ \\
\hline Southern Europe & $\begin{array}{l}-1.839 * * * \\
(21.29)\end{array}$ & $\begin{array}{l}0.310 * * * \\
(24.91)\end{array}$ & $\begin{array}{l}-0.152 * * * \\
(9.47)\end{array}$ & $\begin{array}{l}-0.177 * * * \\
(12.25)\end{array}$ \\
\hline Former Soviet Union & $\begin{array}{l}-0.654 * * * \\
(9.51)\end{array}$ & $\begin{array}{l}0.047 * * * \\
(4.75)\end{array}$ & $\begin{array}{l}0.058^{* * * *} \\
(4.53)\end{array}$ & $\begin{array}{l}-0.085^{* * * *} \\
(7.37)\end{array}$ \\
\hline Poland & $\begin{array}{l}-0.475^{* * * *} \\
(5.89)\end{array}$ & $\begin{array}{l}0.007 \\
(0.58)\end{array}$ & $\begin{array}{l}0.126^{* * *} \\
(8.45)\end{array}$ & $\begin{array}{l}-0.118^{* * * *} \\
(8.77)\end{array}$ \\
\hline Eastern Europe & $\begin{array}{l}-0.175 \\
(1.58)\end{array}$ & $\begin{array}{l}-0.006 \\
(0.41)\end{array}$ & $\begin{array}{l}0.062 * * \\
(3.01)\end{array}$ & $\begin{array}{l}-0.044 * \\
(2.38)\end{array}$ \\
\hline Syria & $\begin{array}{l}-2.281 * * * \\
(28.71)\end{array}$ & $\begin{array}{l}0.391 * * * \\
(34.11)\end{array}$ & $\begin{array}{l}-0.309 * * * \\
(20.91)\end{array}$ & $\begin{array}{l}-0.128^{* * * *} \\
(9.65)\end{array}$ \\
\hline Afghanistan & $\begin{array}{l}-3.200 * * * \\
(28.46)\end{array}$ & $\begin{array}{l}0.292 * * * \\
(17.99)\end{array}$ & $\begin{array}{l}-0.328^{* * *} \\
(15.69)\end{array}$ & $\begin{array}{l}-0.244 * * * \\
(12.97)\end{array}$ \\
\hline Iraq & $\begin{array}{l}-2.867 \text { *** } \\
(19.45)\end{array}$ & $\begin{array}{l}0.188 * * * \\
(18.32)\end{array}$ & $\begin{array}{l}-0.014 * * * \\
(1.05)\end{array}$ & $\begin{array}{l}-0.178^{* * *} \\
(14.96)\end{array}$ \\
\hline MENA & $\begin{array}{l}-2.332 * * * \\
(27.29)\end{array}$ & $\begin{array}{l}0.341 * * * \\
(22.05)\end{array}$ & $\begin{array}{l}-0.314^{* *} \\
(16.07)\end{array}$ & $\begin{array}{l}-0.199 * * * \\
(11.34)\end{array}$ \\
\hline South-Eastern Europe & $\begin{array}{l}-1.419^{* * *} \\
(19.87)\end{array}$ & $\begin{array}{l}0.192 * * * \\
(18.62)\end{array}$ & $\begin{array}{l}-0.015 \\
(1.09)\end{array}$ & $\begin{array}{l}-0.182^{* * * *} \\
(15.27)\end{array}$ \\
\hline Sub-Saharan Africa & $\begin{array}{l}-2.131 \text { *** } \\
(18.20)\end{array}$ & $\begin{array}{l}0.338 * * * \\
(20.06)\end{array}$ & $\begin{array}{l}-0.235^{* * *} \\
(10.84)\end{array}$ & $\begin{array}{l}-0.168^{* * * *} \\
(8.61)\end{array}$ \\
\hline Northern and Western Europe & $\begin{array}{l}0.408 * * * \\
(3.87)\end{array}$ & $\begin{array}{l}-0.094 * * * \\
(6.17)\end{array}$ & $\begin{array}{l}-0.030^{* * *} \\
(1.53)\end{array}$ & $\begin{array}{l}0.134 * * * \\
(7.62)\end{array}$ \\
\hline Asia & $-0.359 * *$ & $0.088 * * *$ & $-0.218 * * *$ & $0.134 * * *$ \\
\hline
\end{tabular}


Table 3 (continued)

\begin{tabular}{lllll}
\hline Variable & EDU & LHS & HS & MHS \\
\hline & $(2.64)$ & $(4.49)$ & $(8.62)$ & $(5.90)$ \\
Remaining countries & $-0.417^{* * *}$ & $0.085^{* * *}$ & $-0.104 * * *$ & $-0.025^{* * * *}$ \\
& $(3.98)$ & $(5.60)$ & $(5.32)$ & $(1.41)$ \\
Adjusted R & 0.200 & 0.199 & 0.121 & 0.025 \\
Sample size & 78,118 & 78,118 & 78,118 & 78,118 \\
\hline
\end{tabular}

Note: $t$-statistics in parentheses; $* \mathrm{p}<0.10, * * \mathrm{p}<0.05$, *** $\mathrm{p}<0.01$; EDU $=$ educational attainment measured by average years of schooling. LHS, HS, and MHS represent dichotomous variables capturing the highest education level with the categories "lower than high school," "high school," and "more than high school"; benchmark group comprises all native adults

educational system in the countries of origin; on the other, many educational biographies are interrupted by war and flight. Further, the immigration of highly qualified immigrants and international students from countries such as India, China, and other Asian countries has gained importance in recent years. Finally, the quality of the education system in the country of origin is also of major importance. Immigrants from countries with poor quality education systems have greater difficulty continuing their education in Germany.

As for education levels, among individuals with a migration background, the share of graduates with a qualification lower than high school is larger, while the share of high school and university graduates is smaller. Here, again, the countries of origin of refugee migration and those of guest worker migration show the worst picture. The only positive exceptions are migrants from northern and western Europe. Here, the signs are reversed, indicating that the probability of obtaining a low-level qualification or no completed school at all is lower, and the probability of obtaining a higher education degree is greater than among German natives.

Finally, we examine the effect of age at immigration more carefully by replacing age at immigration and age at immigration squared with age at immigration group dummies. Table 4 presents the results, where the benchmark is all native adults with no migration background. Hence the age at immigration coefficients show the differences in educational attainment between individuals with a migration background of specified age at immigration groups and native adults.

Column one shows negative significant coefficients for all age groups, indicating that regardless of immigration age, there is always a disadvantage in schooling compared to native adults. However, the slope of the coefficients increases with age at immigration until the teenage years, then decreases. This indicates that the education gap widens with increasing age at arrival, however at a decreasing rate. Thus, we again confirm hypothesis $\mathrm{H} 2$ and identify a nonlinear relationship between age at immigration and education, which suggests that assimilation to a new educational system works better at a young age. While the groups of individuals who immigrated to Germany as infants or elementary school-aged children show a relatively small gap with approximately 1.1 and 1.4 years less schooling as adults compared to non-immigrant adults, adapting to the school system is very difficult for individuals of secondary-school age. Individuals migrating at the age of 13 to 19 show the biggest jump upwards in the gap and have already 2.4 years less education in adulthood. Increased language barriers and 
Table 4 Regression estimates including age at immigration groups - Pooled sample of first-generation, second-generation, and native-parentage adults, Germany, 1984-2018

\begin{tabular}{|c|c|c|c|c|}
\hline Variable & EDU & LHS & HS & MHS \\
\hline Constant & $\begin{array}{l}11.300 * * * \\
(121.17)\end{array}$ & $\begin{array}{l}0.457 * * * \\
(33.73)\end{array}$ & $\begin{array}{l}0.426^{* * * *} \\
(24.68)\end{array}$ & $\begin{array}{l}0.0723^{* * * *} \\
(4.70)\end{array}$ \\
\hline Male & $\begin{array}{l}0.294 * * * \\
(16.08)\end{array}$ & $\begin{array}{l}-0.072 * * * \\
(26.96)\end{array}$ & $\begin{array}{l}0.031 * * * \\
(9.22)\end{array}$ & $\begin{array}{l}0.046^{* * * *} \\
(15.19)\end{array}$ \\
\hline Age & $\begin{array}{l}0.063 * * * \\
(17.38)\end{array}$ & $\begin{array}{l}-0.014 * * * \\
(26.65)\end{array}$ & $\begin{array}{l}0.008^{*} \\
(12.44)\end{array}$ & $\begin{array}{l}0.007 * * * * \\
(12.14)\end{array}$ \\
\hline $\mathrm{Age}^{2}$ & $\begin{array}{l}-0.0008 * * * \\
(24.84)\end{array}$ & $\begin{array}{l}0.0001 \text { *** } \\
(31.36)\end{array}$ & $\begin{array}{l}-0.0001^{* *} \\
(13.45)\end{array}$ & $\begin{array}{l}-0.0001 \text { *** } \\
(14.81)\end{array}$ \\
\hline Eastern Germany & $\begin{array}{l}0.051 * \\
(2.16)\end{array}$ & $\begin{array}{l}-0.054 * * * \\
(15.62)\end{array}$ & $\begin{array}{l}0.040 * * * \\
(9.12)\end{array}$ & $\begin{array}{l}0.011 * * \\
(2.78)\end{array}$ \\
\hline Married & $\begin{array}{l}0.088 * * * \\
(4.18)\end{array}$ & $\begin{array}{l}-0.014 * * * \\
(4.56)\end{array}$ & $\begin{array}{l}-0.013 \text { *** } \\
(3.34)\end{array}$ & $\begin{array}{l}0.023 * * * \\
(6.68)\end{array}$ \\
\hline Second-generation & $\begin{array}{l}-0.216^{* * * *} \\
(4.63)\end{array}$ & $\begin{array}{l}0.067 * * * \\
(9.93)\end{array}$ & $\begin{array}{l}-0.037 * * * \\
(4.25)\end{array}$ & $\begin{array}{l}-0.027 * * \\
(3.45)\end{array}$ \\
\hline \multicolumn{5}{|l|}{ Age at immigration } \\
\hline 0 to 4 & $\begin{array}{l}-1.122 \text { *** } \\
(18.18)\end{array}$ & $\begin{array}{l}0.159 * * * \\
(17.79)\end{array}$ & $\begin{array}{l}-0.099 * * * \\
(8.64)\end{array}$ & $\begin{array}{l}-0.064 * * * \\
(6.26)\end{array}$ \\
\hline 5 to 12 & $\begin{array}{l}-1.399 * * * \\
(20.07)\end{array}$ & $\begin{array}{l}0.186 * * * \\
(18.33)\end{array}$ & $\begin{array}{l}-0.044 * * * \\
(3.45)\end{array}$ & $\begin{array}{l}-0.137 * * * \\
(11.94)\end{array}$ \\
\hline 13 to 19 & $\begin{array}{l}-2.370^{* * * *} \\
(40.21)\end{array}$ & $\begin{array}{l}0.346 * * * \\
(40.46)\end{array}$ & $\begin{array}{l}-0.173 * * * \\
(15.88)\end{array}$ & $\begin{array}{l}-0.178^{* * * *} \\
(18.27)\end{array}$ \\
\hline 20 to 24 & $\begin{array}{l}-2.657 * * * \\
(56.46)\end{array}$ & $\begin{array}{l}0.362 * * * \\
(52.95)\end{array}$ & $\begin{array}{l}-0.314 * * * \\
(36.07)\end{array}$ & $\begin{array}{l}-0.070 * * * \\
(9.03)\end{array}$ \\
\hline 25 to 29 & $\begin{array}{l}-2.724 * * * \\
(60.88)\end{array}$ & $\begin{array}{l}0.344 * * * \\
(54.75)\end{array}$ & $\begin{array}{l}-0.392 * * * \\
(48.89)\end{array}$ & $\begin{array}{l}0.003 \\
(0.48)\end{array}$ \\
\hline 30 to 34 & $\begin{array}{l}-2.959 * * * \\
(60.47)\end{array}$ & $\begin{array}{l}0.383 * * * \\
(53.88)\end{array}$ & $\begin{array}{l}-0.414 * * * \\
(45.75)\end{array}$ & $\begin{array}{l}0.031 \text { **** } \\
(3.78)\end{array}$ \\
\hline 35 to 44 & $\begin{array}{l}-3.116^{* * *} \\
(68.60)\end{array}$ & $\begin{array}{l}0.420 * * * \\
(63.75)\end{array}$ & $\begin{array}{l}-0.418 \text { *** } \\
(49.72)\end{array}$ & $\begin{array}{l}-0.071 \text { *** } \\
(9.35)\end{array}$ \\
\hline 45 to 64 & $\begin{array}{l}-2.936^{* * * *} \\
(47.28)\end{array}$ & $\begin{array}{l}0.390 * * * \\
(43.30)\end{array}$ & $\begin{array}{l}-0.425 * * * \\
(37.04)\end{array}$ & $\begin{array}{l}-0.059 * * * \\
(5.80)\end{array}$ \\
\hline Adjusted $\mathrm{R}^{2}$ & 0.173 & 0.162 & 0.100 & 0.015 \\
\hline Sample size & 78,118 & 78,118 & 78,118 & 78,118 \\
\hline
\end{tabular}

Note: $t$-statistics in parentheses; $* \mathrm{p}<0.10, * * \mathrm{p}<0.05$, *** $\mathrm{p}<0.01$; EDU $=$ educational attainment measured by average years of schooling. LHS, HS, and MHS represent dichotomous variables capturing the highest education level with the categories "lower than high school," "high school," and "more than high school"; benchmark group comprises all native adults

slower social adjustment at this age may be crucial factors. Thereafter, with increasing age at immigration the discrepancy increases, however with a decreasing slope; the differences between the age groups become smaller. This may be because adult immigrants have already completed their education in their country of origin and no longer need to integrate in the German education system. In addition to years of schooling, teenagers and young adults also show the greatest increase in proportions in terms of education levels. While the proportion of individuals without graduation 
and with qualification lower than high school increases to $35 \%$ for this age group, the likelihood of obtaining a high school diploma or university degree is the lowest, namely $18 \%$ lower than the native population.

\section{First-Generation Sample Analysis}

This section focuses on individuals with a direct migration background and examines the subsample of 20,794 first-generation immigrants in depth. Table 5 presents the sample according to country of origin and age at immigration. It is evident that a large share of the immigrant population is from the former Soviet Union (16.36\%), Syria (14.38\%), south-eastern Europe (13.37\%), and Turkey (10.58\%). When considering educational attainment of immigrants from different regions of origin, immigrants from northern and western Europe are observed to have the highest average years of schooling, i.e., approximately 12 years, while immigrants from Syria, Afghanistan and Iraq have the lowest educational attainment, with three to four years less schooling than northern and western European immigrants, and the highest age at immigration. While migrants from Turkey, Italy, and other southern European countries also show low numbers in terms of years of education, they are much younger at immigration than refugee migrants.

Considering age at immigration, all age groups have lower educational attainment than native-born adults, i.e., 12.35 years of schooling on average (see Table 1). Again, educational attainment decreases with increasing age at immigration where migration at secondary school age is associated with the greatest losses with regard to education, while the numbers show little difference from age 20 onward.

To account for the determinants of educational attainment of individuals with a direct migration background, we regress the education specifications for the subsample of first-generation migrants separately. The OLS results are presented in Table 6. Among first-generation immigrants, education increases with age at a decreasing rate, indicated by the positive and negative sign of age and age squared. Further, the education level results imply that the probability of obtaining more education increases with age. The negative result of age at immigration together with the positive result of age at immigration squared again confirms the non-linear relationship assumed in hypothesis $\mathrm{H} 2$ and reveal that as age at immigration increases, educational attainment falls, but at a decreasing rate. ${ }^{9}$ The results for education levels are not as clear. As age at immigration increases, the likelihood of a qualification lower or higher than high school increases, while the likelihood of high school graduation decreases. The differences between eastern and western Germany do not seem to play a major role. The magnitude of the coefficient is quite small and the effect is of low significance.

Table 7 shows the regression results of first-generation immigrants where country of origin is included with the benchmark group of immigrants from northern and western Europe. The results are similar to the pooled sample results of overall generations. Again, in line with hypothesis $H 3$, we find significant differences for different regions of origin. First-generation immigrants from Asia and the group of resettled Germans

\footnotetext{
${ }^{9}$ To ensure the robustness of our findings over time, we additionally run analyses where we divide our sample into sub-periods according to the SOEP waves (i.e., 1984-95, 1996-2007, and 2008-2018). The results are available in Table 10 in the appendix and support our main findings.
} 
Table 5 Summary statistics of first-generation immigration adults by country of origin and age at immigration, Germany, 1984-2018

\begin{tabular}{|c|c|c|c|}
\hline Country of origin & Sample size & Educational attainment & Age at immigration \\
\hline Turkey & $2,200(10.58)^{\mathrm{a}}$ & $9.44(1.91)^{b}$ & $19.85(11.44)^{b}$ \\
\hline Italy & $1,030(4.95)$ & $9.46(1.92)$ & $21.41(11.97)$ \\
\hline Southern Europe & $1,300(6.25)$ & $9.67(2.17)$ & $23.77(12.29)$ \\
\hline Former Soviet Union & $3,401(16.36)$ & $10.80(1.94)$ & $28.36(15.00)$ \\
\hline Poland & $1,551(7.46)$ & $11.03(2.03)$ & $24.19(14.40)$ \\
\hline Eastern Europe & $586(2.82)$ & $11.27(2.26)$ & $18.60(16.42)$ \\
\hline Syria & $2,990(14.38)$ & $9.12(1.98)$ & $35.75(10.23)$ \\
\hline Afghanistan & $726(3.49)$ & $8.26(1.96)$ & $33.56(11.47)$ \\
\hline Iraq & $903(4.34)$ & $8.56(1.90)$ & $34.17(10.71)$ \\
\hline MENA & $937(4.51)$ & $9.97(2.18)$ & $27.74(11.27)$ \\
\hline South-Eastern Europe & $2,781(13.37)$ & $10.08(2.02)$ & $25.68(12.70)$ \\
\hline Sub-Saharan Africa & $619(2.98)$ & $9.40(2.31)$ & $27.26(9.26)$ \\
\hline Northern and Western Europe & $693(3.33)$ & $11.96(2.37)$ & $20.76(14.09)$ \\
\hline Asia & 404 (1.94) & $11.17(2.44)$ & $24.40(10.87)$ \\
\hline Remaining countries & $677(3.26)$ & $11.37(2.62)$ & $19.11(15.78)$ \\
\hline \multicolumn{4}{|l|}{ Age at immigration } \\
\hline 0 to 4 & $1,786(8.59)^{\mathrm{a}}$ & $11.30(2.61)^{\mathrm{b}}$ & \\
\hline 5 to 12 & $1,421(6.83)$ & $11.24(2.52)$ & \\
\hline 13 to 19 & $2,008(9.66)$ & $10.26(2.26)$ & \\
\hline 20 to 24 & $3,305(15.89)$ & $9.96(2.07)$ & \\
\hline 25 to 29 & $3,954(19.02)$ & $9.91(2.10)$ & \\
\hline 30 to 34 & $2,955(14.21)$ & $9.68(2.10)$ & \\
\hline 35 to 44 & 3,449 (16.59) & 9.49 (1.99) & \\
\hline 45 to 64 & $1,774(8.53)$ & $9.43(1.99)$ & \\
\hline Total & $20,794(100)$ & $10.01(2.24)$ & $26.69(13.80)$ \\
\hline
\end{tabular}

${ }^{\text {a }}$ Percentage of foreign-born individuals in parentheses

${ }^{\mathrm{b}}$ Standard deviations in parentheses

from the former Soviet Union, Poland, and other eastern European countries show the smallest differences in obtained education and the likelihood of obtaining a certain qualification.

Again, the result for the group of resettled Germans shows that due to their prior knowledge of the German language and culture, they find it easier to adapt to the German educational system. This emphasizes the importance of language for successful educational integration.

The biggest disadvantage in education can be observed for the group of migrants from the MENA region. Afghanistan and Iraq show the poorest outcomes with 3.3 and 3.0 years less education than the benchmark group, respectively. Considerable deficits can also be identified for the southern European countries, Turkey, and Sub-Saharan Africa with an education gap of more than 2 years. For these countries and regions, the probability of obtaining a higher education degree is also the lowest. 
Table 6 Regression estimates of first-generation adults, Germany, 1984-2018

\begin{tabular}{|c|c|c|c|c|}
\hline Variable & EDU & LHS & HS & MHS \\
\hline Constant & $\begin{array}{l}9.795 * * * \\
(62.79)\end{array}$ & $\begin{array}{l}0.627 * * * \\
(17.66)\end{array}$ & $\begin{array}{l}0.111 * * * \\
(3.49)\end{array}$ & $\begin{array}{l}0.152 * \\
(5.28)\end{array}$ \\
\hline Male & $\begin{array}{l}-0.058 \\
(1.94)\end{array}$ & $\begin{array}{l}-0.024 * * * \\
(3.47)\end{array}$ & $\begin{array}{l}0.057 * * * \\
(9.35)\end{array}$ & $\begin{array}{l}-0.014^{*} \\
(2.47)\end{array}$ \\
\hline Age & $\begin{array}{l}0.068 * * * \\
(9.96)\end{array}$ & $\begin{array}{l}-0.014 * * * \\
(9.24)\end{array}$ & $\begin{array}{l}0.017 * * * \\
(12.00)\end{array}$ & $\begin{array}{l}0.001 \\
(0.64)\end{array}$ \\
\hline $\mathrm{Age}^{2}$ & $\begin{array}{l}-0.0006^{* * * *} \\
(8.34)\end{array}$ & $\begin{array}{l}0.0001 * * * \\
(7.80)\end{array}$ & $\begin{array}{l}0.0001 * * * \\
(8.33)\end{array}$ & $\begin{array}{l}-0.0000^{* * * *} \\
(1.59)\end{array}$ \\
\hline Eastern Germany & $\begin{array}{l}0.141^{*} \\
(2.52)\end{array}$ & $\begin{array}{l}-0.050^{* * * *} \\
(3.93)\end{array}$ & $\begin{array}{l}-0.039 * * * \\
(3.40)\end{array}$ & $\begin{array}{l}0.064 * * * \\
(6.21)\end{array}$ \\
\hline Married & $\begin{array}{l}-0.172 * * * \\
(4.94)\end{array}$ & $\begin{array}{l}0.027 * * * \\
(3.36)\end{array}$ & $\begin{array}{l}0.020^{* * *} \\
(2.82)\end{array}$ & $\begin{array}{l}-0.016^{* * * *} \\
(2.43)\end{array}$ \\
\hline Age at immigration & $\begin{array}{l}-0.073 * * * \\
(22.19)\end{array}$ & $\begin{array}{l}0.010^{* * * *} \\
(13.66)\end{array}$ & $\begin{array}{l}-0.014 * * * \\
(21.28)\end{array}$ & $\begin{array}{l}0.004^{* * * *} \\
(6.53)\end{array}$ \\
\hline Age at immigration $2 / 100$ & $\begin{array}{l}0.050 * * * \\
(8.69)\end{array}$ & $\begin{array}{l}-0.001 * * * \\
(6.82)\end{array}$ & $\begin{array}{l}0.009 * * * \\
(7.19)\end{array}$ & $\begin{array}{l}-0.004 * * * \\
(3.92)\end{array}$ \\
\hline Adjusted $\mathrm{R}^{2}$ & 0.074 & 0.024 & 0.086 & 0.008 \\
\hline Sample size & 20,794 & 20,794 & 20,794 & 20,794 \\
\hline
\end{tabular}

Note: $t$-statistics in parentheses; $* \mathrm{p}<0.10, * * \mathrm{p}<0.05$, *** $\mathrm{p}<0.01$; EDU $=$ educational attainment measured by average years of schooling. LHS, HS and MHS represent dichotomous variables capturing the highest education level with the categories "lower than high school," "high school," and "more than high school;" benchmark group comprises all native adults

Finally, we include age-at-immigration groups for the sample of first-generation immigrants to investigate the non-linearity between age at immigration and education hypothesized in $H 3$ in more detail. The results are presented in Table 8 and report the effects relative to the benchmark category of foreign-born adults who immigrated at age 25-29. The results confirm our previous findings and indicate a nonlinear relationship between age at immigration and educational attainment. Migrants who migrate at a young age show on average 1.4 years more education. There is a big jump in the gap between the categories 5-12 and 13-19, indicating that migrating in this age groups can be expected to lead to difficulties integrating in the new school system and overall lower educational attainment in terms of years of schooling and educational achievement. In addition, individuals migrating between the ages of 13 and 19 are the least likely to obtain a university degree later on.

\section{Conclusion}

Immigrants and their children face remarkable challenges and barriers regarding educational attainment compared to their native counterparts. Our analysis examines the magnitude and significance of this disparity in opportunities for immigrants and their children in Germany and explores the process of intergenerational education assimilation. In addition, we simultaneously account for the possible effect of cultural 
Table 7 Regression estimates including country of origin - First-generation adults, Germany, 1984-2018

\begin{tabular}{|c|c|c|c|c|}
\hline Variable & EDU & LHS & HS & MHS \\
\hline Constant & $\begin{array}{l}11.82^{* * * *} \\
(70.19)\end{array}$ & $\begin{array}{l}0.308^{* * * *} \\
(7.80)\end{array}$ & $\begin{array}{l}0.244 * * * \\
(6.89)\end{array}$ & $\begin{array}{l}0.423^{* * * *} \\
(12.99)\end{array}$ \\
\hline Male & $\begin{array}{l}0.238^{* * * *} \\
(8.48)\end{array}$ & $\begin{array}{l}-0.057 \text { *** } \\
(8.72)\end{array}$ & $\begin{array}{l}0.088^{* * * *} \\
(14.83)\end{array}$ & $\begin{array}{l}-0.001 \text { *** } \\
(0.23)\end{array}$ \\
\hline Age & $\begin{array}{l}0.050 * * * \\
(7.73)\end{array}$ & $\begin{array}{l}-0.013 \text { *** } \\
(8.30)\end{array}$ & $\begin{array}{l}0.013 * * * \\
(9.12)\end{array}$ & $\begin{array}{l}0.001 \\
(0.54)\end{array}$ \\
\hline $\mathrm{Age}^{2}$ & $\begin{array}{l}-0.0005 * * * \\
(8.58)\end{array}$ & $\begin{array}{l}0.0001 \text { *** } \\
(8.71)\end{array}$ & $\begin{array}{l}-0.0001 * * \\
(7.87)\end{array}$ & $\begin{array}{l}-0.0001 * * * \\
(2.07)\end{array}$ \\
\hline Eastern Germany & $\begin{array}{l}0.069 \\
(1.31)\end{array}$ & $\begin{array}{l}-0.028^{*} \\
(2.27)\end{array}$ & $\begin{array}{l}-0.033 * * \\
(2.97)\end{array}$ & $\begin{array}{l}0.047 * * * \\
(4.58)\end{array}$ \\
\hline Married & $\begin{array}{l}-0.123 * * * \\
(3.74)\end{array}$ & $\begin{array}{l}-0.024 * * \\
(3.11)\end{array}$ & $\begin{array}{l}-0.015^{*} \\
(2.11)\end{array}$ & $\begin{array}{l}-0.012 \\
(1.85)\end{array}$ \\
\hline Age at immigration & $\begin{array}{l}-0.059 * * * \\
(18.92)\end{array}$ & $\begin{array}{l}0.008 * * * \\
(10.86)\end{array}$ & $\begin{array}{l}-0.012 * * * \\
(18.82)\end{array}$ & $\begin{array}{l}0.005 * * * \\
(8.43)\end{array}$ \\
\hline Age at immigration ${ }^{2} / 100$ & $\begin{array}{l}0.049 * * * \\
(8.94)\end{array}$ & $\begin{array}{l}-0.009 \text { *** } \\
(6.68)\end{array}$ & $\begin{array}{l}0.010^{* * * *} \\
(8.58)\end{array}$ & $\begin{array}{l}-0.005 * * * \\
(5.00)\end{array}$ \\
\hline \multicolumn{5}{|l|}{ Country of origin: } \\
\hline Turkey & $\begin{array}{l}-2.573 * * * \\
(29.41)\end{array}$ & $\begin{array}{l}0.464^{* * * *} \\
(22.64)\end{array}$ & $\begin{array}{l}-0.108^{* * *} \\
(5.87)\end{array}$ & $\begin{array}{l}-0.400 * * * \\
(23.61)\end{array}$ \\
\hline Italy & $\begin{array}{l}-2.496 * * * \\
(-25.36)\end{array}$ & $\begin{array}{l}0.433^{* * * *} \\
(18.77)\end{array}$ & $\begin{array}{l}-0.101 * * * \\
(4.85)\end{array}$ & $\begin{array}{l}-0.360 * * * \\
(18.91)\end{array}$ \\
\hline Southern Europe & $\begin{array}{l}-2.201 * * * \\
(-23.35)\end{array}$ & $\begin{array}{l}0.402^{* * * *} \\
(18.17)\end{array}$ & $\begin{array}{l}-0.118^{* * *} \\
(5.94)\end{array}$ & $\begin{array}{l}-0.312 * * * \\
(17.12)\end{array}$ \\
\hline Former Soviet Union & $\begin{array}{l}-0.914 * * * \\
(10.80)\end{array}$ & $\begin{array}{l}0.129^{* * * *} \\
(6.51)\end{array}$ & $\begin{array}{l}0.119^{* * * *} \\
(6.64)\end{array}$ & $\begin{array}{l}-0.232 * * * \\
(14.19)\end{array}$ \\
\hline Poland & $\begin{array}{l}-0.810^{* * * *} \\
(8.83)\end{array}$ & $\begin{array}{l}0.095^{* * * *} \\
(4.42)\end{array}$ & $\begin{array}{l}0.177 * * * \\
(9.18)\end{array}$ & $\begin{array}{l}-0.264 * * * \\
(14.86)\end{array}$ \\
\hline Eastern Europe & $\begin{array}{l}-0.679 * * * \\
(5.99)\end{array}$ & $\begin{array}{l}0.085^{* * * *} \\
(3.21)\end{array}$ & $\begin{array}{l}0.107 * * * \\
(4.49)\end{array}$ & $\begin{array}{l}-0.189 * * * \\
(8.60)\end{array}$ \\
\hline Syria & $\begin{array}{l}-2.397 * * * \\
(26.80)\end{array}$ & $\begin{array}{l}0.462^{* * * *} \\
(22.06)\end{array}$ & $\begin{array}{l}-0.228^{* * * *} \\
(12.11)\end{array}$ & $\begin{array}{l}-0.398 * * * \\
(23.45)\end{array}$ \\
\hline Afghanistan & $\begin{array}{l}-3.315 * * * \\
(30.04)\end{array}$ & $\begin{array}{l}0.360^{* * * *} \\
(13.94)\end{array}$ & $\begin{array}{l}-0.242 * * * \\
(10.42)\end{array}$ & $\begin{array}{l}-0.285^{* * *} \\
(16.44)\end{array}$ \\
\hline Iraq & $\begin{array}{l}-2.992 * * * \\
(28.53)\end{array}$ & $\begin{array}{l}0.414^{* * * *} \\
(16.84)\end{array}$ & $\begin{array}{l}-0.237 * * * \\
(10.73)\end{array}$ & $\begin{array}{l}-0.354 * * * \\
(17.43)\end{array}$ \\
\hline MENA & $\begin{array}{l}-1.793 * * * \\
(17.57)\end{array}$ & $\begin{array}{l}0.370^{* * * *} \\
(15.45)\end{array}$ & $\begin{array}{l}-0.162 * * * \\
(7.50)\end{array}$ & $\begin{array}{l}-0.228^{* * * *} \\
(11.51)\end{array}$ \\
\hline South-Eastern Europe & $\begin{array}{l}-1.710 * * * \\
(19.98)\end{array}$ & $\begin{array}{l}0.277^{* * * *} \\
(13.81)\end{array}$ & $\begin{array}{l}0.035 \\
(1.92)\end{array}$ & $\begin{array}{l}-0.324 * * * \\
(19.57)\end{array}$ \\
\hline Sub-Saharan Africa & $\begin{array}{l}-2.366^{* * * *} \\
(20.96)\end{array}$ & $\begin{array}{l}0.428^{* * * *} \\
(16.19)\end{array}$ & $\begin{array}{l}-0.165^{* * *} \\
(6.92)\end{array}$ & $\begin{array}{l}-0.337 * * * \\
(15.42)\end{array}$ \\
\hline Asia & $\begin{array}{l}-0.617 * * * \\
(4.90)\end{array}$ & $\begin{array}{l}0.171^{* * * *} \\
(5.81)\end{array}$ & $\begin{array}{l}-0.153 * * * \\
(5.76)\end{array}$ & $\begin{array}{l}-0.018 \\
(0.73)\end{array}$ \\
\hline Remaining countries & $\begin{array}{l}-0.702 * * * \\
(6.46)\end{array}$ & $\begin{array}{l}0.169^{* * * *} \\
(6.65)\end{array}$ & $\begin{array}{l}-0.053^{*} \\
(2.33)\end{array}$ & $\begin{array}{l}-0.117 * * * \\
(5.58)\end{array}$ \\
\hline Adjusted $\mathrm{R}^{2}$ & 0.203 & 0.108 & 0.166 & 0.060 \\
\hline Sample size & 20,794 & 20,794 & 20,794 & 20,794 \\
\hline
\end{tabular}

Note: $t$-statistics in parentheses; $* \mathrm{p}<0.10, * * \mathrm{p}<0.05$, *** $\mathrm{p}<0.01$; EDU $=$ educational attainment measured by average years of schooling. LHS, HS and MHS represent dichotomous variables capturing the highest education level with the categories "lower than high school," "high school," and "more than high school;" benchmark group includes all foreign-born adults from northern and western Europe 
Table 8 Regression estimates including age at immigration groups - First-generation adults, Germany, 1984 2018

\begin{tabular}{|c|c|c|c|c|}
\hline Variable & EDU & LHS & HS & MHS \\
\hline Constant & $\begin{array}{l}8.054 * * * \\
(48.48)\end{array}$ & $\begin{array}{l}0.845 * * * \\
(22.38)\end{array}$ & $\begin{array}{l}-0.283 * * * \\
(8.37)\end{array}$ & $\begin{array}{l}0.245^{* * *} * \\
(8.03)\end{array}$ \\
\hline Male & $\begin{array}{l}0.058 \\
(1.95)\end{array}$ & $\begin{array}{l}-0.023 * * * \\
(3.43)\end{array}$ & $\begin{array}{l}0.059 * * * \\
(9.57)\end{array}$ & $\begin{array}{l}-0.014 * * \\
(2.62)\end{array}$ \\
\hline Age & $\begin{array}{l}0.077^{* * * *} \\
(10.90)\end{array}$ & $\begin{array}{l}-0.016^{* * * *} \\
(9.84)\end{array}$ & $\begin{array}{l}0.019 * * * \\
(12.75)\end{array}$ & $\begin{array}{l}0.003^{*} \\
(2.00)\end{array}$ \\
\hline $\mathrm{Age}^{2}$ & $\begin{array}{l}-0.0007 * * * \\
(9.80)\end{array}$ & $\begin{array}{l}0.0001 * * * \\
(8.55)\end{array}$ & $\begin{array}{l}-0.0001 * * * \\
(9.43)\end{array}$ & $\begin{array}{l}-0.0001 * * \\
(3.21)\end{array}$ \\
\hline Eastern Germany & $\begin{array}{l}0.159 * * \\
(2.84)\end{array}$ & $\begin{array}{l}-0.052 * * * \\
(4.04)\end{array}$ & $\begin{array}{l}0.024 * \\
(2.06)\end{array}$ & $\begin{array}{l}0.053 * * * \\
(5.11)\end{array}$ \\
\hline Married & $\begin{array}{l}-0.162 * * * \\
(4.65)\end{array}$ & $\begin{array}{l}-0.025 * * \\
(3.21)\end{array}$ & $\begin{array}{l}-0.019 * * \\
(2.64)\end{array}$ & $\begin{array}{l}-0.016^{* *} \\
(2.43)\end{array}$ \\
\hline \multicolumn{5}{|l|}{ Age at immigration } \\
\hline 0 to 4 & $\begin{array}{l}1.400 * * * \\
(22.62)\end{array}$ & $\begin{array}{l}-0.159 * * * \\
(11.31)\end{array}$ & $\begin{array}{l}0.266^{* * * *} \\
(21.05)\end{array}$ & $\begin{array}{l}-0.064^{* * * *} \\
(5.62)\end{array}$ \\
\hline 5 to 12 & $\begin{array}{l}1.411 * * * \\
(21.17)\end{array}$ & $\begin{array}{l}-0.165 * * * \\
(10.90)\end{array}$ & $\begin{array}{l}0.363 * * * \\
(26.70)\end{array}$ & $\begin{array}{l}-0.142^{* * * *} \\
(11.63)\end{array}$ \\
\hline 13 to 19 & $\begin{array}{l}0.380 * * * \\
(6.44)\end{array}$ & $\begin{array}{l}0.002 \\
(0.14)\end{array}$ & $\begin{array}{l}0.217 * * * \\
(18.01)\end{array}$ & $\begin{array}{l}-0.175^{* * * *} \\
(16.18)\end{array}$ \\
\hline 20 to 24 & $\begin{array}{l}0.113 * \\
(2.24)\end{array}$ & $\begin{array}{l}0.014 \\
(1.24)\end{array}$ & $\begin{array}{l}0.088 * * * \\
(8.54)\end{array}$ & $\begin{array}{l}-0.073^{* * * *} \\
(7.91)\end{array}$ \\
\hline 30 to 34 & $\begin{array}{l}-0.269 * * * \\
(0.14)\end{array}$ & $\begin{array}{l}0.043^{* * * *} \\
(3.61)\end{array}$ & $\begin{array}{l}-0.037 * * * \\
(3.44)\end{array}$ & $\begin{array}{l}-0.023^{*} \\
(2.38)\end{array}$ \\
\hline 35 to 44 & $\begin{array}{l}-0.555^{* * *} \\
(10.62)\end{array}$ & $\begin{array}{l}0.095^{* * * *} \\
(8.03)\end{array}$ & $\begin{array}{l}-0.071 * * * \\
(6.70)\end{array}$ & $\begin{array}{l}-0.053^{* * * *} \\
(5.57)\end{array}$ \\
\hline 45 to 64 & $\begin{array}{l}-0.669 * * * \\
(10.13)\end{array}$ & $\begin{array}{l}0.100^{* * * *} \\
(6.62)\end{array}$ & $\begin{array}{l}-0.127 * * * \\
(9.43)\end{array}$ & $\begin{array}{l}-0.037 * * \\
(3.02)\end{array}$ \\
\hline Adjusted $\mathrm{R}^{2}$ & 0.075 & 0.027 & 0.095 & 0.020 \\
\hline Sample size & 20,794 & 20,794 & 20,794 & 20,794 \\
\hline
\end{tabular}

Note: $t$-statistics in parentheses; $* \mathrm{p}<0.10, * * \mathrm{p}<0.05$, *** $\mathrm{p}<0.01$; EDU $=$ educational attainment measured by average years of schooling. LHS, HS, and MHS represent dichotomous variables capturing the highest education level with the categories "lower than high school," "high school," and "more than high school;" benchmark group includes all foreign-born adults who immigrated at age 25-29

characteristics and life-cycle effects. Using data from the German Socio-Economic Panel for the period 1984-2018, we analyze the determinants of differences in educational output between first- and second-generation immigrants and individuals without a migration background and investigate the effect of country of origin and age at immigration.

The results show that on average, immigrants face significant educational disadvantages relative to natives. First-generation immigrants have fewer years of schooling than native-born Germans and have a disproportionate share of lower educational qualifications (Haupt- and Realschule). Some do not complete 
secondary school at all. The probability of obtaining a higher qualification that enables university admission is lower. This gap between immigrants and natives is highly driven by age at immigration, with immigration age and education revealing a nonlinear relationship. While the gap is relatively small among individuals who migrate at a young age, integrating in the school system at secondary school age is more difficult, leading to large disadvantages. Examining the educational mobility of immigrants in Germany, we identify an intergenerational catch-up in education. Children of immigrants seem to have greater educational aspirations than their parents, so the gap in education between immigrants and natives is reduced for the second generation. On average, second-generation immigrants lag only 0.16 years of schooling behind their native peers and have reduced disparities in educational levels. Hence, our results suggest educational convergence toward the level of the native population. Finally, the results show large differences in educational outcomes with regard to country and region of origin, indicating that regional origin may account for much of the education gap. While immigrants with an ethnic background closer to the German language and culture show the best education outcomes, immigrants from Turkey, Italy, and other southern European countries, who came mainly as unskilled guest workers, and especially the group of war refugees from Syria, Afghanistan, Iraq, and other MENA countries, have the lowest educational attainment. Accordingly, the major practical contribution of the present research is that it provides differentiated results that help better understand the educational differences between immigration groups and the assimilation process over time. It provides an up-to-date overview of educational outcomes of immigrants in Germany differentiated with respect to generation, origin, and age at arrival. Drawing on the most recent data further allows us to consider the latest wave of migration, which had previously received little attention in the literature.

Based on these findings, educational policies should actively aim to facilitate the inclusion of migrants and migrant children and alleviate their disadvantages in the education system. Since a large number of newly arrived children and adolescents had to be integrated into the schools, especially with the last wave of migration of refugees from 2015 onwards, the models designed in a rush are far from mature. What is urgently needed now are well-founded concepts that schools can use as guidelines. An integrated approach to educational inclusion should ideally incorporate differences based on origin and include a combination of linguistic and academic support as well as cultural integration. The implementation of these concepts must be scientifically monitored. In addition, more qualified personnel are needed for the integration of newly immigrated children and adolescents. This includes not only teachers with knowledge of teaching German as a foreign language, but also social workers and educators who can advise and support families in their diverse concerns. The introduction of a free effective early-childhood education and care system could enhance children's language proficiency and improve their educational opportunities in school. The transition from elementary to secondary school plays a major role in Germany. The right choice of secondary school is a cornerstone of subsequent educational success. Therefore, education policy should seek to support immigrant families in this 
decision. Schools have to act proactively toward immigrant parents to support the transition process by providing information on the schooling options available to their children and helping parents to overcome potential barriers to accessing the school of their choice. Further, a more comprehensive and less selective educational system could improve migrant student opportunities. In addition, the secondary-school age group is confronted with increasing integration problems caused by higher language and cultural barriers. Previous studies have shown that integration in ordinary classes with simultaneous language tuition leads to better educational outcomes than preparatory language courses that delay school entry (Esser, 2006; Massumi et al., 2015) and that school integration should follow a holistic teaching and learning approach that incorporates language, learning, and psychosocial support (European Commission, 2019).

In addition, immigrants are at risk of racism and structural discrimination in the German education system. This problem should be made more visible and explicitly anchored in the curricula and school laws of the federal states as well as in the training curricula for teachers through comprehensive anti-racism education practices. Students of vulnerable groups should be targeted and informed about their rights. In parallel, the anti-discrimination infrastructure in schools and education should be strengthened by establishing independent, external counseling, complaint, and intervention centers. The extent of racist discrimination in schools, universities and other educational institutions should be recorded through studies.

We would like to point out that the measurement of education in our analysis is based on a quantitative approach (number of years of education). We additionally attempt to capture the quality of education by alternatively considering the highest educational qualification - divided into three categories - as the dependent variable. However, we want to note that further and more detailed qualitative approaches could help to capture the actual gap in education more precisely. Comparisons of quantitative indicators such as PISA (Schleicher, 2019) and Trends in International Mathematics and Science Study results (Schwippert et al., 2020) show that this gap may in fact be even larger than that identified by quantitative approaches. Qualitative indicators show that children with a migration background lag years behind German students in the same age group (Luessenhop \& Kaiser, 2020). When interpreting our results, it should also be considered that the education systems in the countries of origin are not directly comparable with that in Germany and that qualifications cannot always be classified without difficulty.

Furthermore, as our analysis is based on correlations, no direct causal relationships can be established. Future research with individual observation of educational trajectories over time under different circumstances would go beyond identifying pure correlations to provide an in-depth analysis of the relationship between migration background, educational outcomes, and factors promoting integration, subsequently enabling causal statements. Moreover, our analysis sheds light on just one part of integration, albeit a very important one since education is an important prerequisite for economic success. However, a multilayered perspective of the integration process with a consideration of educational, cultural, and economic integration could deliver a more comprehensive picture. 


\section{Appendix}

\section{Data appendix}

- Educational attainment: SOEP variable code - D11109\$\$. This variable indicates the number of years of education completed at the time of the survey for all individuals in the household aged 16 and older. For more details, see SOEP Survey Paper 772 (Series D), 2020. ${ }^{10}$

- Other sub-dependent variables for other equations of education with respect to high school were derived from SOEP variable code D11108\$\$. This variable indicates the highest level of education (less than high school, completed high school, or more than high school) of all individuals in the household aged 16 and older. For detailed information see Table 9.

- Age: SEOP variable code - D11101\$\$. The variable indicates the age of the individual.

- Birth year: SEOP variable code - gebjahr. Indicates respondent's year of birth. This variable is used to calculate age at immigration.

- Immigration year: SEOP variable code - immiyear. It contains information on the year of immigration to Germany for all persons who have ever been a part of a SOEP household and who were not born in Germany. This variable is used to calculate age at immigration. For more details, see SOEP Survey Paper 862 (Series D), 2020. ${ }^{11}$

- Age at immigration: Age at immigration is calculated as the difference between immigration year (immiyear) and birth year (gebjahr).

- Migration background: SEOP variable code - migback. This variable is derived from the respondents' background information depending on the place of birth. By definition, a direct migration background is assigned the code " 2 - direct migration background," respondents born in Germany whose parents have no migration background are assigned the code " 1 - no migration background," and respondents whose father or mother have a migration background are assigned the code "3 indirect migration background." For more details, see SOEP Survey Paper 862 (Series D), 2020.

- Country of origin: SOEP variable code - corigin. corigin contains information on the country of birth of all persons who have ever been a part of a SOEP household. Respondents who were born in Germany are assigned the code "1." Persons who were not born in Germany are assigned a country of birth other than Germany depending on the information given in the wave-specific questionnaires. For more details, see SOEP Survey Paper 862 (Series D), 2020. The country variables are used as dummies as described in Table 9. The following classification of countries and regions has been used for the analysis:

- Turkey

- Italy

- Southern Europe: Greece, Spain, and Portugal.

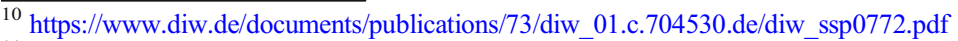

${ }^{11}$ https://www.diw.de/documents/publikationen/73/diw_01.c.789390.de/diw_ssp0862.pdf
} 
- Former Soviet Union: Russian Federation, Ukraine, Kazakhstan, Belarus, Georgia, Azerbaijan, Kyrgyz Republic, Armenia, Uzbekistan, Moldova, Tajikistan, Turkmenistan, Latvia, Lithuania, and Estonia.

- Poland

- Eastern Europe: Hungary, Czech Republic, and Slovakia.

- Syrian Arab Republic

- Afghanistan

- Iraq

- MENA: Algeria, Bahrain, Arab Republic of Egypt, Islamic Republic of Iran, Israel, Jordan, Kuwait, Lebanon, Libya, Morocco, Qatar, Saudi Arabia, Sudan, Pakistan, Palestine, Tunisia, and Yemen.

- South-Eastern Europe: Albania, Bosnia/Herzegovina, Bulgaria, Croatia, Former Yugoslavia, Macedonian, Montenegro, Rumania, Serbia, and Slovenia.

- Sub-Saharan Africa: Angola, Benin, Botswana, Burkina Faso, Cabo Verde, Cameroon, Central African Republic, Chad, Comoros, Democratic Republic of Congo, Cote D' Ivoire, Equatorial Guinea, Eritrea, Ethiopia, The Gambia, Ghana, Guinea, Kenya, Lesotho, Liberia, Madagascar, Mali, Mauritius, Mozambique, Namibia, Niger, Nigeria, Rwanda, Senegal, Seychelles, Sierra Leone, Somalia, South Africa, Tanzania, Togo, Uganda, Zambia, and Zimbabwe.

- Northern and Western Europe: Austria, Belgium, Denmark, Finland, France, Ireland, Lichtenstein, Luxembourg, Monaco, The Netherlands, Sweden, Switzerland, Norway, and United Kingdom.

- Asia: Bangladesh, Bhutan, Burkina Faso, Burma, Cambodia, China, Hongkong, India, Indonesia, Japan, Malaysia, Mongolia, Myanmar, Pakistan, Philippines, Singapore, Sri Lanka, South Korea, Taiwan, Thailand, Nepal, and Vietnam.

- Remaining countries: all countries not included in the country groups described above. 


\section{Robustness checks}

Table 9 Definition of variables

\begin{tabular}{|c|c|c|c|}
\hline Variable & Code & Code of SOEP & Description \\
\hline $\begin{array}{c}\text { Dependent } \\
\text { variable }\end{array}$ & Educational attainment & D11109\$\$ & $\begin{array}{l}\text { Educational attainment } \\
\text { measured in years of } \\
\text { education }\end{array}$ \\
\hline \multicolumn{4}{|c|}{ Sub-dependent variables } \\
\hline $\begin{array}{l}\text { Lower than high } \\
\text { school (LHS) }\end{array}$ & $\begin{array}{l}\text { - Intermediate secondary school } \\
\text { (Realschule) } \\
\text { - Lower secondary school } \\
\quad \text { (Hauptschule) } \\
\text { - Other } \\
\text { - None }\end{array}$ & $\begin{array}{l}\text { D11108\$\$ } \\
\text { SOEP Format } \\
\text { is } 1\end{array}$ & $\begin{array}{l}\text { Dichotomous variable; equal } \\
\text { to one for indicated } \\
\text { characteristic; otherwise } \\
\text { zero }\end{array}$ \\
\hline High school (HS) & $\begin{array}{l}\text { - Upper secondary school certificate } \\
\text { giving access to university (Abitur) } \\
\text { - Advanced university of applied } \\
\text { science entrance qualification } \\
\text { (Fachhochschulreife) } \\
\text { - Apprenticeship (Lehre) } \\
\text { - Specialized vocational school } \\
\text { (Berufsfachschule) }\end{array}$ & $\begin{array}{l}\text { D11108\$\$ } \\
\text { SOEP Format } \\
\text { is } 2\end{array}$ & $\begin{array}{l}\text { Dichotomous variable; equal } \\
\text { to one for indicated } \\
\text { characteristic; otherwise } \\
\text { zero }\end{array}$ \\
\hline $\begin{array}{l}\text { More than high } \\
\text { school (MHS) }\end{array}$ & $\begin{array}{l}\text { - School of health care (Schule des } \\
\text { Gesundheitswesens) } \\
\text { - University of applied sciences } \\
\text { (Fachhochschule) } \\
\text { - University } \\
\text { - Technical university usually requiring } \\
\text { practical training as part of the } \\
\text { course (Technische Universität) } \\
\text { - Civil service training }\end{array}$ & $\begin{array}{l}\text { D11108\$\$ } \\
\text { SOEP Format } \\
\text { is } 3\end{array}$ & $\begin{array}{l}\text { Dichotomous variable; equal } \\
\text { to one for indicated } \\
\text { characteristic; otherwise } \\
\text { zero }\end{array}$ \\
\hline
\end{tabular}

Explanatory variables:

$\begin{array}{ll}\text { Gender variable } & \text { Male } \\ \text { Age variables } & \text { Age } \\ & \text { Age }^{2} \\ \begin{array}{c}\text { Year of } \\ \text { immigration }\end{array} & \text { Immiyear } \\ \begin{array}{c}\text { Age at } \\ \text { immigration }\end{array} & \text { Ageimmig } \\ \begin{array}{c}\text { Region of } \\ \text { residence }\end{array} & \text { Ageimmig } 2 \\ & \text { Eastern Germany (1) }\end{array}$

D11102LL SOEP Format is 1

D11101

-

immiyear

$-$

D11102\$\$

SOEP Format is 1 for east Germany
Dichotomous variable; equal to one for male and zero for female

Age - valued from 0- 105

Age squared

Calendar year of immigration

Age at immigration

Age at immigration squared

Dichotomous variable; equal to one for indicated characteristic; otherwise zero

Western Germany (2) 
Table 9 (continued)

\begin{tabular}{|c|c|c|c|}
\hline Variable & Code & Code of SOEP & Description \\
\hline & & $\begin{array}{l}\text { SOEP Format } \\
\text { is } 2 \text { for west } \\
\text { Germany }\end{array}$ & $\begin{array}{l}\text { Dichotomous variable; equal } \\
\text { to one for indicated } \\
\text { characteristic; otherwise } \\
\text { zero }\end{array}$ \\
\hline Marital status & $\begin{array}{l}\text { Married } \\
\text {-Married/ living with partner } \\
\text {-Widowed }\end{array}$ & $\begin{array}{l}\text { D11104\$\$ } \\
\text { SOEP Format } \\
\text { is } 1 \text { and } 3\end{array}$ & respectively. \\
\hline \multicolumn{4}{|l|}{$\begin{array}{l}\text { Dichotomous } \\
\text { variable; equal } \\
\text { to one for } \\
\text { indicated } \\
\text { characteristic; } \\
\text { otherwise zero }\end{array}$} \\
\hline $\begin{array}{l}\text { Age at } \\
\text { immigration } \\
\text { variables* }\end{array}$ & $\begin{array}{l}0 \text { to } 4 \\
5 \text { to } 12 \\
13 \text { to } 19 \\
20 \text { to } 24 \\
25 \text { to } 29 \\
30 \text { to } 34 \\
35 \text { to } 44 \\
45 \text { to } 64\end{array}$ & $\begin{array}{l}\text { Derived from } \\
\text { 'immiyear' } \\
\text { and } \\
\text { 'gebjahr' }\end{array}$ & $\begin{array}{l}\text { Dichotomous variable; equal } \\
\text { to one for indicated } \\
\text { characteristic; otherwise } \\
\text { zero }\end{array}$ \\
\hline $\begin{array}{l}\text { Country-of-origin } \\
\text { variables }\end{array}$ & $\begin{array}{l}\text { Turkey } \\
\text { Italy } \\
\text { Southern Europe } \\
\text { Former Soviet Union } \\
\text { Poland } \\
\text { Eastern Europe } \\
\text { Syrian Arab Republic } \\
\text { Afghanistan } \\
\text { Iraq } \\
\text { MENA } \\
\text { South-Eastern Europe } \\
\text { Sub-Saharan Africa } \\
\text { Northern and western Europe } \\
\text { Asia } \\
\text { Remaining countries }\end{array}$ & corigin & $\begin{array}{l}\text { Dichotomous variable; equal } \\
\text { to one for indicated } \\
\text { characteristic; otherwise } \\
\text { zero }\end{array}$ \\
\hline \multirow[t]{2}{*}{$\begin{array}{l}\text { Immigrant } \\
\text { generation } \\
\text { variables }\end{array}$} & $\begin{array}{l}\text { First-generation } \\
\text {-Direct migration background }\end{array}$ & migback & $\begin{array}{l}\text { Dichotomous variable; equal } \\
\text { to one for indicated } \\
\text { characteristic; otherwise } \\
\text { zero }\end{array}$ \\
\hline & $\begin{array}{l}\text { Second generation } \\
\text {-Indirect migration background } \\
\text { Native-born adults } \\
\text { - No migration background }\end{array}$ & & \\
\hline
\end{tabular}

Source: SOEP Survey Paper 862 (Series D), 2020; SOEP Survey Paper 772 (Series D), 2020 
Table 10 Regression estimates as per the survey year groups for first-generation immigrants

\begin{tabular}{|c|c|c|c|}
\hline \multirow[t]{2}{*}{ Variable } & $1984-95$ & 1996-2007 & 2008-2018 \\
\hline & EDU & EDU & EDU \\
\hline Constant & $\begin{array}{l}11.16^{* * * *} \\
(21.36)\end{array}$ & $\begin{array}{l}11.57 * * * \\
(26.57)\end{array}$ & $\begin{array}{l}9.17 * * * \\
(51.47)\end{array}$ \\
\hline Male & $\begin{array}{l}0.580 * * * \\
(6.33)\end{array}$ & $\begin{array}{l}0.240 * * * \\
(2.83)\end{array}$ & $\begin{array}{l}0.013 \\
(0.38)\end{array}$ \\
\hline Age & $\begin{array}{l}-0.012 \\
(0.47)\end{array}$ & $\begin{array}{l}-0.009 \\
(0.51)\end{array}$ & $\begin{array}{l}0.098 * * * \\
(12.92)\end{array}$ \\
\hline $\mathrm{Age}^{2}$ & $\begin{array}{l}0.0002 \\
(0.63)\end{array}$ & $\begin{array}{l}-0.0001 \\
(0.77)\end{array}$ & $\begin{array}{l}-0.0008^{* * * *} \\
(9.97)\end{array}$ \\
\hline Age at immigration & $\begin{array}{l}-0.101 * * * \\
(9.30)\end{array}$ & $\begin{array}{l}-0.045^{* * *} \\
(6.56)\end{array}$ & $\begin{array}{l}-0.079 * * * \\
(9.97)\end{array}$ \\
\hline Age at immigration ${ }^{2} / 100$ & $\begin{array}{l}0.145 * * * \\
(6.80)\end{array}$ & $\begin{array}{l}0.063 * * * \\
(4.76)\end{array}$ & $\begin{array}{l}0.041 * * * \\
(5.89)\end{array}$ \\
\hline Adjusted $\mathrm{R}^{2}$ & 0.128 & 0.044 & 0.100 \\
\hline Sample size & 1,959 & 2,784 & 16,051 \\
\hline
\end{tabular}

Note: $t$-statistics in parentheses; $* \mathrm{p}<0.10, * * \mathrm{p}<0.05$, *** $\mathrm{p}<0.01$; EDU $=$ educational attainment measured by average years of schooling

Funding Open Access funding enabled and organized by Projekt DEAL.

Open Access This article is licensed under a Creative Commons Attribution 4.0 International License, which permits use, sharing, adaptation, distribution and reproduction in any medium or format, as long as you give appropriate credit to the original author(s) and the source, provide a link to the Creative Commons licence, and indicate if changes were made. The images or other third party material in this article are included in the article's Creative Commons licence, unless indicated otherwise in a credit line to the material. If material is not included in the article's Creative Commons licence and your intended use is not permitted by statutory regulation or exceeds the permitted use, you will need to obtain permission directly from the copyright holder. To view a copy of this licence, visit http://creativecommons.org/licenses/by/4.0/.

\section{References}

Alba, R. D., Handl, J., \& Müller, W. (2017). Ethnische Ungleichheit im deutschen Bildungssystem, Kölner Zeitschrift für Soziologie und Sozialpsychologie: KZfSS., 69(Supp. 1), 619-644.

Algan, Y., Dustmann, C., Glitz, A., \& Manning, A. (2010). The economic situation of first and secondgeneration immigrants in France, Germany and the United Kingdom. The Economic Journal, 120(542), 4-30.

Batalova, J., \& Feldblum, M. (2020). Immigrant-origin students in U.S. higher education: a data profile. migration policy institute, https:/www.migrationpolicy.org/research/immigrant-origin-students-ushigher-education. Accessed 12 Jul 2021

Baumert, J., Watermann, R., \& Schümer, G. (2003). Disparitäten der Bildungsbeteiligung und des Kompetenzerwerbs. Zeitschrift für Erziehungswissenschaft, 6(1), 46-71.

Bertoli, S., \& Brücker, H. (2011). Selective immigration policies, migrants' education and welfare at origin. Economics Letters, 113(1), 19-22.

Björklund, A., \& Salvanes, K. G. (2011). Education and family background: mechanisms and policies. In Handbook of the Economics of Education, 3, 201-247. Elsevier.

Böhlmark, A. (2008). Age at immigration and school performance: a siblings analysis using Swedish register data. Labour Economics, 15(6), 1366-1387. 
Bönke, T., \& Neidhöfer, G. (2018). Parental background matters: intergenerational mobility and assimilation of Italian immigrants in Germany. German Economic Review, 19(1), 1-31.

Borjas, G. J. (1993). The intergenerational mobility of immigrants. Journal of Labor Economics, 11(1, Part 1), $113-135$.

Borjas, G. J. (2006). Native internal migration and the labor market impact of immigration. Journal of Human Resources, 41(2), 221-258.

Borjas, G. J. (2019). Immigration and economic growth. National Bureau of Economic Research Working Paper 25836. Available at NBER: http://www.nber.org/papers/w25836.

Boubtane, E., Dumont, J. C., \& Rault, C. (2016). Immigration and economic growth in the OECD countries 1986-2006. Oxford Economic Papers, 68(2), 340-360.

Bove, V., \& Elia, L. (2017). Migration, diversity, and economic growth. World Development, 89, 227-239.

Burchardi, K. B., Chaney, T., Hassan, T. A., Tarquinio, L., \& Terry, S. J. (2020). Immigration, innovation, and growth. National Bureau of Economic Research Working Paper 27075. Available at NBER: http://www. nber.org/papers/w27075.

Chiswick, B. R., \& DebBurman, N. (2004). Educational attainment: analysis by immigrant generation. Economics of Education Review, 23(4), 361-379.

Chiswick, B. R., \& Miller, P. W. (1994). The determinants of post-immigration investments in education. Economics of Education Review, 13(2), 163-177.

Chiswick, B. R., \& Sullivan, T. A. (1995). The new immigrants. State of the union: America in the 1990s. Social Trends, 2, 211-270.

Cohen, Y., Zach, T., \& Chiswick, B. (1997). The educational attainment of immigrants: changes over time. The Quarterly Review of Economics and Finance, 37, 229-243.

Corak, M. (2012). Age at immigration and the education outcomes of children. In A. Masten, K. Liebkind, \& D. J. Hernandez (Eds.), Realizing the potential of immigrant youth (pp. 90-116). Cambridge University Press.

Cortes, K. E. (2006). The effects of age at arrival and enclave schools on the academic performance of immigrant children. Economics of Education Review, 25(2), 121-132.

De Paola, M., \& Brunello, G. (2016). Education as a tool for the economic integration of migrants. IZA Discussion Paper No. 9836, Available at SSRN: https://ssrn.com/abstract=2757926.

Destatis (2020). Migration und integration, Retrieved from: https:/www.destatis.de/DE/Themen/GesellschaftUmwelt/Bevoelkerung/Migration-Integration/_inhalt.html.

Diehl, C., Hunkler, C., \& Kristen, C. (2016). Ethnische Ungleichheiten im Bildungsverlauf. Eine Einführung. In Ethnische Ungleichheiten im Bildungsverlauf (pp. 3-31). Springer VS.

Dimitrova, R., Chasiotis, A., \& Van de Vijver, F. (2016). Adjustment outcomes of immigrant children and youth in Europe. European Psychologist, 21, 150-162.

Docquier, F., \& Machado, J. (2016). Global competition for attracting talents and the world economy. The World Economy, 39(4), 530-542.

Drouhot, L. G., \& Nee, V. (2019). Assimilation and the second generation in Europe and America: blending and segregating social dynamics between immigrants and natives. Annual Review of Sociology, 45, 177199.

Esser, H. (2006). Migration, Sprache und Integration (AKI-Forschungsbilanz, 4). Wissenschaftszentrum Berlin für Sozialforschung gGmbH FSP Zivilgesellschaft, Konflikte und Demokratie Arbeitsstelle Interkulturelle Konflikte und gesellschaftliche Integration -AKI https://nbn-resolving.org/urn:nbn:de: 0168-ssoar-113493.

European Commission. (2019). Integration von Schülern mit Migrationshintergrund an Schulen in Europa: nationale politische Strategien und Maßnahmen. In Eurydice-Bericht. Amt für Veröffentlichungen der Europäischen Union. https://doi.org/10.2797/83185.

Feliciano, C. (2005). Educational selectivity in US immigration: how do immigrants compare to those left behind? Demography, 42(1), 131-152.

Fick, P. (2011). Berufliche Bildungschancen von Migranten in Deutschland und die Bedeutung von Generation und Herkunft. Zeitschrift für Soziologie der Erziehung und Sozialisation: ZSE, 31(3), 280295.

Gang, I. N., \& Zimmermann, K. F. (2000). Is child like parent? Educational attainment and ethnic origin. Journal of Human Resources, 35(3), 550-569.

German Federal Statistical Office (2020). Bevölkerung und Erwerbstätigkeit: Bevölkerung mit Migrationshintergrund - Ergebnisse des Mikrozensus 2019. Fachserie 1 Reihe 2.2, No. 2010220197004.

Hartmann, J. (2016). Do second-generation Turkish migrants in Germany assimilate into the middle class? Ethnicities, 16(3), 368-392. 
Herzer, D. (2017). Refugee immigration and total factor productivity. International Economic Journal, 31(3), 390-414.

Ho, G., \& Turk-Ariss, R. (2018). The Labor market integration of migrants in europe: new evidence from micro data. International Monetary Fund, Working Paper 18/232.

Hradil, S., \& Schiener, J. (2001). Soziale Ungleichheit in Deutschland. Springer-Verlag.

Kahn, L. M. (2004). Immigration, skills and the labor market: international evidence. Journal of Population Economics, 17(3), 501-534.

Kao, G., \& Thompson, J. S. (2003). Racial and ethnic stratification in educational achievement and attainment. Annual Review of Sociology, 29(1), 417-442.

Kirui, D. K., \& Kao, G. (2018). Does generational status matter in college? Expectations and academic performance among second-generation college students in the US. Ethnicities, 18(4), 571-602.

Kristen, C., \& Granato, N. (2007). The educational attainment of the second generation in Germany: social origins and ethnic inequality. Ethnicities, 7(3), 343-366.

Lauderdale, M. K., \& Heckman, S. J. (2017). Family background and higher education attainment among children of immigrants. Journal of Family and Economic Issues, 38(3), 327-337.

Legewie, N., \& Bohmann, S. (2018). Upward and downward social mobility probabilities have converged for men and women. DIW Weekly Report, 8(20), 169-178.

Lemmermann, D., \& Riphahn, R. T. (2018). The causal effect of age at migration on youth educational attainment. Economics of Education Review, 63, 78-99.

Luessenhop, M., \& Kaiser, G. (2020). Refugees and numeracy: what can we learn from international largescale assessments, especially from TIMSS? ZDM, 52(3), 541-555.

Maehler, D. B., Massing, N., \& Rammstedt, B. (2014). Grundlegende Kompetenzen Erwachsener mit Migrationshintergrund im internationalen Vergleich: PIAAC 2012 (p. 236). Waxmann.

Massumi, M., von Dewitz, N., Grießbach, J., Terhart, H., Wagner, K., Hippmann, K., \& Altinay, L. (2015). Neu zugewanderte Kinder und Jugendliche im deutschen Schulsystem. Bestandsaufnahme und Empfehlungen. Mercator-Institut für Sprachförderung und Deutsch als Zweitsprache und Zentrum für LehrerInnenbildung der Universität zu Köln.

Müller, A. G., \& Stanat, P. (2006). Schulischer Erfolg von Schülerinnen und Schülern mit Migrationshintergrund: Analysen zur Situation von Zuwanderern aus der ehemaligen Sowjetunion und aus der Türkei. In In Herkunftsbedingte Disparitäten im Bildungswesen: Differenzielle Bildungsprozesse und Probleme der Verteilungsgerechtigkeit (pp. 221-255). VS Verlag für Sozialwissenschaften.

Nee, V., \& Alba, R. (2013). Assimilation as rational action in contexts defined by institutions and boundaries (p. 355). The Handbook of Rational Choice Social Research.

OECD. (2016a). PISA 2015: PISA - results in Focus. OECD Publishing. https://doi.org/10.1787/aa9237e6-en.

OECD (2016b). Skills matter: further results from the survey of adult skills, OECD Skills Studies, OECD Publishing, Paris, https://doi.org/10.1787/9789264258051-en.

OECD (2017). Catching up? Intergenerational mobility and children of immigrants, OECD Publishing, https:// doi.org/10.1787/9789264288041-en.

OECD (2018a). A broken social elevator? How to promote social mobility, OECD Publishing. https://doi.org/ 10.1787/9789264301085-en.

OECD (2018b), Catching up? Country studies on intergenerational mobility and children of immigrants, OECD Publishing, https://doi.org/10.1787/9789264301030-en.

Peri, G. (2012). The effect of immigration on productivity: evidence from US states. Review of Economics and Statistics, 94(1), 348-358.

Ramírez-Rodríguez, R., \& Dohmen, D. (2010). Ethnisierung von geringer Bildung. In In Bildungsverlierer (pp. 289-311). VS Verlag für Sozialwissenschaften.

Reiss, K., Sälzer, C., Schiepe-Tiska, A., Klieme, E., \& Köller, O. (2016). PISA 2015. In Eine Studie zwischen Kontinuität und Innovation. Waxmann.

Riphahn, R. T. (2003). Cohort effects in the educational attainment of second generation immigrants in Germany: an analysis of census data. Journal of Population Economics, 16(4), 711-737.

Schaafsma, J., \& Sweetman, A. (2001). Immigrant earnings: age at immigration matters. Canadian Journal of Economics, 34, 1066-1099.

Schleicher, A. (2019). PISA 2018: Insights and interpretations. OECD Publishing. https://www.oecd.org/pisa/ PISA\%202018\%20Insights\%20and\%20Interpretations\%20FINAL\%20PDF.pdf.

Schnabel, K. U., \& Schwippert, K. (2000). Einflüsse sozialer und ethnischer Herkunft beim Übergang in die Sekundarstufe II und den Beruf. In In TIMSS/III Dritte Internationale Mathematik- und Naturwissenschaftsstudie - Mathematische und naturwissenschaftliche Bildung am Ende der Schullaufbahn (pp. 261-300). VS Verlag für Sozialwissenschaften. 
Schnepf, S. V. (2007). Immigrants' educational disadvantage: an examination across ten countries and three surveys. Journal of Population Economics, 20(3), 527-545.

Schwippert, K., Kasper, D., Köller, O., McElvany, N., Selter, C., Steffensky, M., \& Wendt, H. (2020). TIMSS 2019: Mathematische und naturwissenschaftliche Kompetenzen von Grundschulkindern in Deutschland im internationalen Vergleich. Waxmann Verlag..

Segeritz, M., Walter, O., \& Stanat, P. (2010). Muster des schulischen Erfolgs von jugendlichen Migranten in Deutschland: Evidenz für segmentierte Assimilation? KZfSS Kölner Zeitschrift für Soziologie und Sozialpsychologie, 62(1), 113-138.

Siegert, M. (2008). Schulische Bildung von Migranten in Deutschland (Working Paper der Forschungsgruppe des Bundesamtes) (p. 13). Bundesamt für Migration und Flüchtlinge https://nbn-resolving.org/urn:nbn:de: 0168-ssoar-382559.

Socio-Economic Panel (SOEP), (2020) data for years 1984-2018, version 35, SOEP, doi: https://doi.org/10. 5684/soep-core.v35.

Stanat, P. (2006). Disparitaten im schulischen Erfolg: Forschungsstand zur Rolle des Migrationshintergrunds. Unterrichtswissenschaft, 34(2), 98.

Stoewe, K. (2017). Bildungsstand von Geflüchteten: Bildung und Ausbildung in den Hauptherkunftsländern, Institut der Deutschen Wirtschaft Köln, IW-Report, 37/2017, https://www.econstor.eu/bitstream/10419/ 172679/1/1009897470.pdf.

Sweetman, A., \& van Ours, J. C. (2015). Immigration: what about the children and grandchildren? In Handbook of the economics of international migration, 1,1141-1193, North-Holland.

Taylor, P., Cohn, D. V., Passel, J. S., Livingston, G., Wang, W., Funk, C., Gonzalez-Barrera, A., Morin, R., Patten, E., \& Motel, S. (2013). Second-generation Americans: a portrait of the adult children of immigrants. PewResearchCenter, 7, 1-130 www.pewresearch.org.

Tran, V. C., Lee, J., \& Huang, T. J. (2019). Revisiting the Asian second-generation advantage. Ethnic and Racial Studies, 42(13), 2248-2269.

van Ours, J. C. \& Veenman, J. (2001). The educational attainment of second generation immigrants in the Netherlands. IZA Discussion Paper No. 297. Available at SSRN: https://ssrn.com/abstract=270790.

van Ours, J. C., \& Veenman, J. (2006). Age at immigration and educational attainment of young immigrants. Economics Letters, 90(3), 310-316.

Walter, O. (2008). Lesekompetenz und Bildungserfolg der Schülerinnen und Schüler mit Migrationshintergrund: Wie lassen sich Unterschiede erklären (pp. 69-84). Bildungserfolg, Migration und Zweisprachigkeit-Perspektiven für Forschung und Entwicklung.

Waters, M. C., \& Gerstein Pineau, M. E. (2016). The integration of immigrants into American society. The National Academies Press. https://doi.org/10.17226/21746.

Weiß, A., \& Nussbaum Bitran, I. (2019). Migration, Sozialstruktur und Ungleichheit in Deutschland und Europa (pp. 1-33). Handbuch Migrationssoziologie.

Yuksel, M. (2009). Intergenerational mobility of immigrants in Germany: moving with natives or stuck in their neighborhoods? IZA Discussion Paper No. 4677. Available at SSRN: https://ssrn.com/abstract= 1530681 .

Publisher's Note Springer Nature remains neutral with regard to jurisdictional claims in published maps and institutional affiliations.

\section{Affiliations}

\section{Thomas Gries $^{1}$ - Margarete Redlin ${ }^{1} \cdot$ Moonum Zehra ${ }^{1}$}

Thomas Gries

thomas.gries@wiwi.upb.de

Moonum Zehra

moonumzehra@live.com

1 University of Paderborn, Center for International Economics, Warburger Str. 100, 33098 Paderborn, Germany 